\title{
Development of Energy Efficiency Indicators in Russia
}

International Energy Agency

Nathalie Trudeau and Isabel Murray

WORKING PAPER 
The International Energy Agency (IEA), an autonomous agency, was established in November 1974. Its mandate is two-fold: to promote energy security amongst its member countries through collective response to physical disruptions in oil supply and to advise member countries on sound energy policy.

The IEA carries out a comprehensive programme of energy co-operation among 28 advanced economies, each of which is obliged to hold oil stocks equivalent to 90 days of its net imports. The Agency aims to:

- Secure member countries' access to reliable and ample supplies of all forms of energy; in particular, through maintaining effective emergency response capabilities in case of oil supply disruptions.

- Promote sustainable energy policies that spur economic growth and environmental protection in a global context - particularly in terms of reducing greenhouse-gas emissions that contribute to climate change.

- Improve transparency of international markets through collection and analysis of energy data.

- Support global collaboration on energy technology to secure future energy supplies and mitigate their environmental impact, including through improved energy

efficiency and development and deployment of low-carbon technologies.

- Find solutions to global energy challenges through engagement and dialogue with non-member countries, industry, international organisations and other stakeholders.

\section{Austria}

International Energy Agency

9 rue de la Fédération

75739 Paris Cedex 15, France

www.iea.org

Please note that this publication is subject to specific restrictions that limit its use and distribution. The terms and conditions are available online at www.iea.org/about/copyright.asp

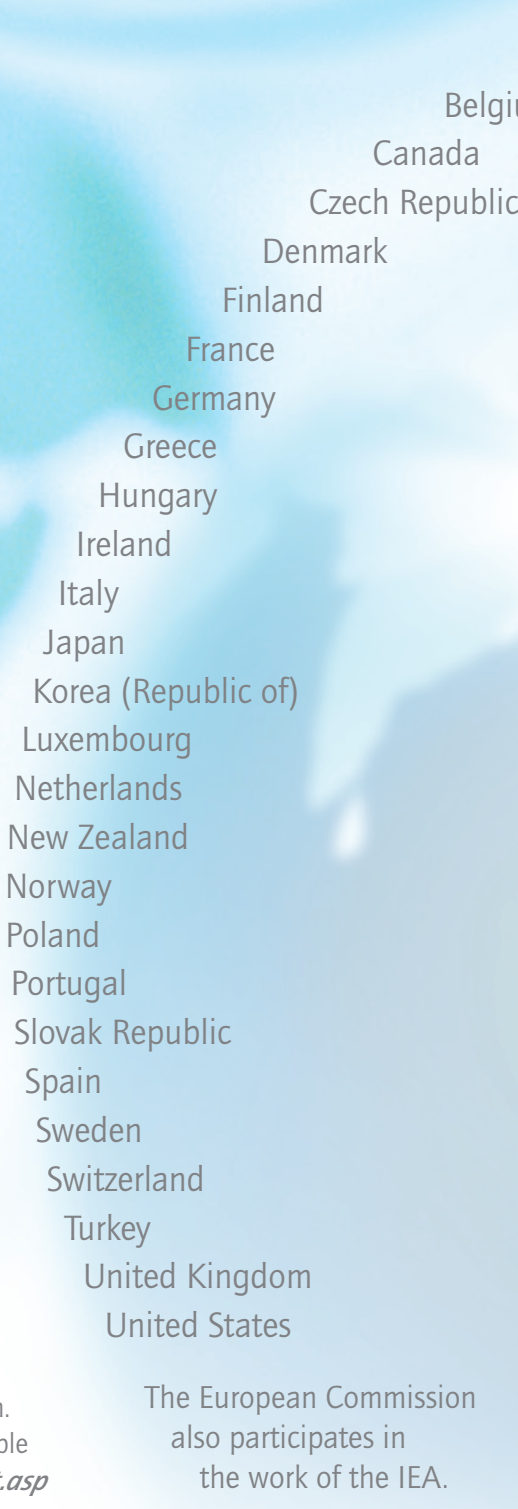

Belgium

\section{Canada}

Czech Republic

\section{Denmark}

\section{France}

Germany

Greece

Hungary

Ireland

Italy

Japan

Korea (Republic of)

Luxembourg

Netherlands

New Zealand

Norway

Poland

Portuga

Slovak Republic

Spain

Sweden

Switzerland

Turkey

United Kingdom

United States

\author{
the work of the IEA
}




\section{Development of Energy Efficiency Indicators in Russia}

The views expressed in this working paper are those of the authors and do not necessarily reflect the views or policy of the International Energy Agency (IEA) Secretariat or of its individual member countries. This paper is a work in progress, designed to elicit comments and further debate; thus, comments are welcome, directed to the authors at: nathalie.trudeau@iea.orgor isabel.murray@iea.org

InTERnational Energy Agency

Nathalie Trudeau and ISABEL MURRAY 


\section{Table of contents}

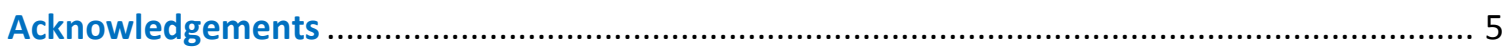

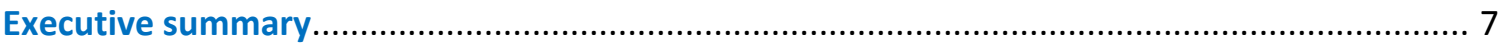

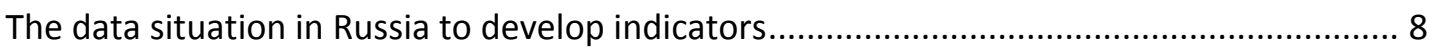

Introduction: the use of indicators to unravel the complexity of energy consumption .............. 10

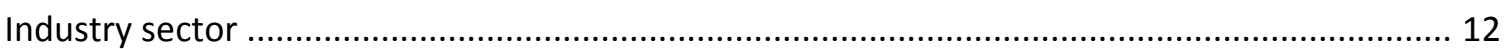

Availability of industry data in Russia to develop indicators................................................ 13

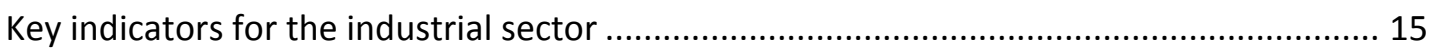

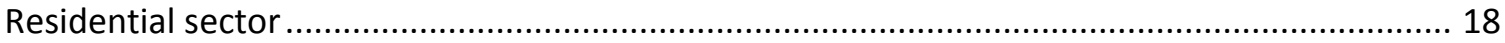

Availability of residential data in Russia to develop indicators ............................................ 19

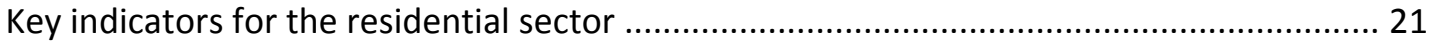

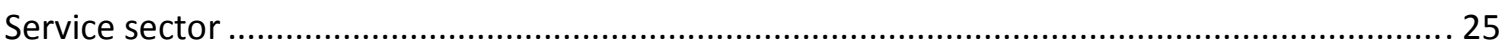

Availability of service data in Russia to develop indicators.................................................. 25

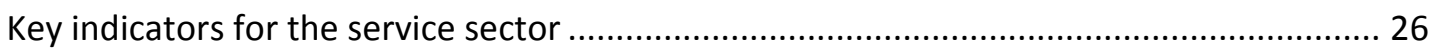

Transport sector

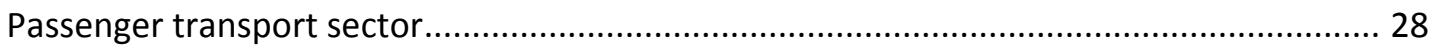

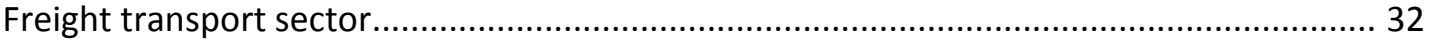

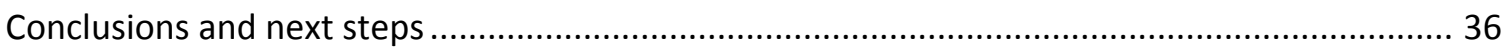

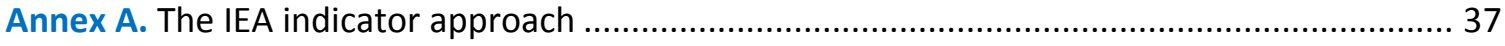

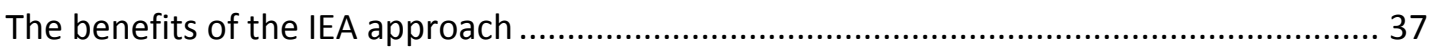

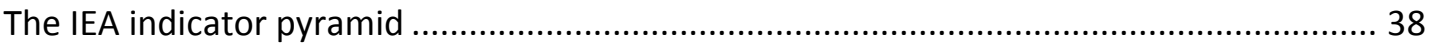

Annex B. The IEA methodology for analysing energy consumption ........................................... 46

The decomposition of changes in energy consumption........................................................ 46

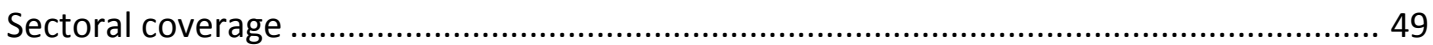

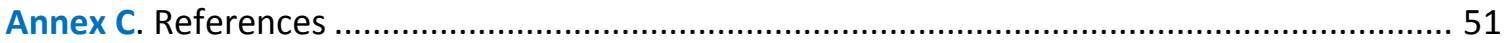

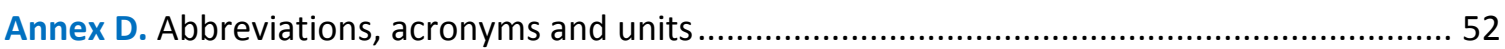

\section{List of figures}

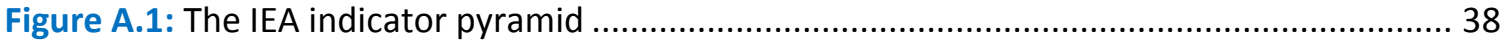

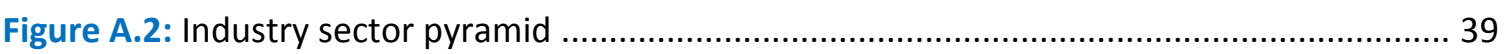

Figure A.3: Residential sector pyramid based on floor area......................................................... 41

Figure A.4: Residential sector pyramid based on household ................................................... 42

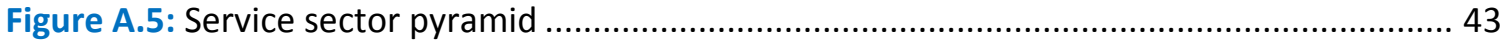

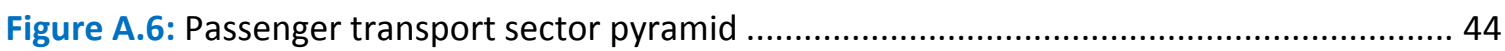

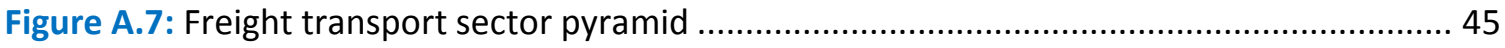

Figure B.1: Basic overview of factors in $\mathrm{CO}_{2}$ decomposition ................................................ 49

Figure B.2: Disaggregation of sectors, sub-sectors and end-uses in

IEA energy indicators approach. 


\section{List of tables}

Table 1: Industry data needed to develop basic energy and energy efficiency indicators

Table 2: Key indicators to understand trends in energy and

Table 3: Residential data needed to develop basic energy and energy efficiency indicators.

Table 4: Key indicators to understand trends in energy and energy efficiency in residential

Table 5: Service data needed to develop basic energy and energy efficiency indicators.

Table 6: Key indicators to understand trends in energy and energy efficiency in services

Table 7: Passenger transport data needed to develop basic energy and energy efficiency indicators.

Table 8: Key indicators to understand trends in energy and energy efficiency in passenger transport

Table 9: Freight transport data needed to develop basic energy and energy efficiency indicators.

Table 10: Key indicators to understand trends in energy and energy efficiency in freight transport

Table B.1: Summary of variables used for the decomposition

\section{List of boxes}

Box 1: The IEA energy efficiency indicators template 11

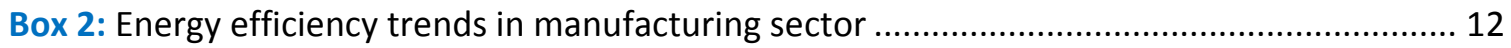

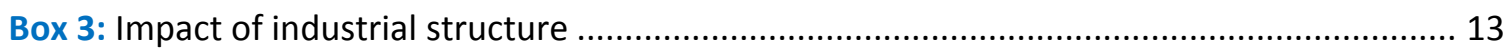

Box 4: The benefits of energy efficiency indicators for companies ............................................ 14

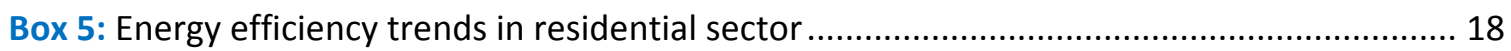

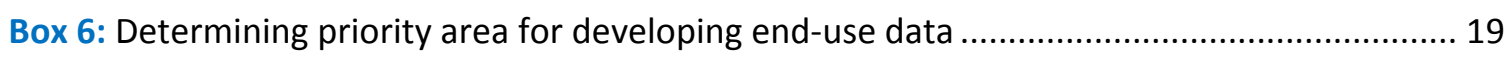

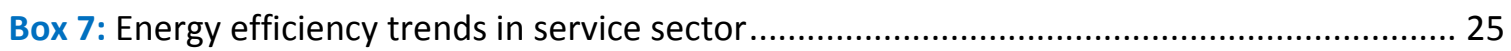

Box 8: Energy efficiency trends in passenger transport sector ................................................... 28

Box 9: Energy efficiency trends in freight transport sector ..................................................... 32 


\section{Acknowledgements}

This work was undertaken by the International Energy Agency (IEA) with funding from the Foreign and Commonwealth Office of the United Kingdom Government under the Strategic Programme Fund.

This paper was prepared by the IEA Directorate of Sustainable Energy Policy and Technology in collaboration with the Directorate of Global Energy Dialogue. The lead authors are Nathalie Trudeau and Isabel Murray.

Special thanks go to Jean-Yves Garnier, Head of IEA Energy Statistics Division, Peter Taylor, Head of IEA Energy Technology Policy Division and Ann Eggington, former Head of IEA Europe, Middle East and Africa Division, for their continuous support and encouragement throughout the project.

Editorial and production assistance provided by Anne Mayne and Marilyn Smith added significantly to the overall quality of the report.

Many other colleagues have provided helpful contributions, particularly François Cuenot, Davide d'Ambrosio, Michel Francoeur, Philippine de T'Serclaes and Anna Zyzniewski.

The IEA and the authors wish to thank the Federal State Statistics Service (Rosstat) of the Russian Federation for their close co-operation throughout the project with special thanks to Alexander Goncharov, Deputy Director, Department of Foreign Statistics and International Co-operation, Rosstat. The IEA would also like to thank the Russian Energy Agency for their co-operation over 2010 on energy efficiency indicators.

The IEA would also like to thank all the participants of the Round Table on Energy Efficiency Indicators in Russia, held in Moscow on 20 September 2010, for their valuable insights on this issue. The IEA and the authors welcome their feedback on this working paper and look forward to continued co-operation. 



\section{Executive summary}

For decades, countries around the world have used aggregate indicators to construct a "big picture" of patterns of energy use. One of the most commonly used aggregate indicators is energy intensity: the measure of energy consumption per unit of gross domestic product (GDP). According to this indicator, Russia led G8 countries ${ }^{1}$ in the reduction of energy intensity over the 1990s; Russia's energy intensity having improved by $2.5 \%$ a year. From 2000 to 2007, Russian energy intensity experienced an even higher rate of improvement with an average annual decrease of over $5 \%$.

However, the usefulness of this indicator is limited and can be misleading; in actual fact, energy intensity is driven by many factors that are not necessarily related to energy efficiency. So it is perfectly possible to have improving energy efficiency, while still seeing rises in energy consumption (the inverse is also true). For instance, given the increase in international hydrocarbon prices during the 2000-07 period and the consequent growth in Russia's GDP, it is likely that the decline in energy intensity seen during this time frame was linked more to economic growth rather than improved energy efficiency.

This speaks to the need for mechanisms that can deliver a better understanding of the factors that affect energy intensity, not only within a given country but on a sector-by-sector basis that adequately reflects that country's economic landscape. Moreover, as each main sector ${ }^{2}$ is influenced by different underlying factors, different explanatory data will be needed depending on the sector analysed. Much more detailed - and disaggregated - data than are currently available in standard energy balances are needed for each main end-use sector to assess the role of energy efficiency and the potential for further energy savings.

Over the past years, the International Energy Agency (IEA) has been developing energy efficiency indicators for each end-use sector, with the specific aim of helping to disentangle the various factors that drive and restrain energy use. Much of this work has been driven by the fact that improved energy efficiency is a shared policy goal of many governments around the world. The benefits of more efficient use of energy are well known and include reduced investments in energy infrastructure, lower fossil-fuel dependency, increased competitiveness and improved consumer welfare. Efficiency gains can also deliver environmental benefits by reducing greenhouse-gas emissions and local air pollution.

In recent years, the IEA has worked closely with Russia to improve energy data collection in general. While some progress has been made, much more work is required: most data required to understand past trends, assess the largest potential for energy savings and enhance energy efficiency policies are currently not available.

Despite the data gaps identified, analysis of some sectors of the economy indicates that there is a large energy savings potential in Russia. In fact, Russia is sometimes referred to as "the Saudi Arabia of energy efficiency"; its vast potential to reduce inefficient or wasteful energy consumption can be considered a significant "energy reserve". One IEA study estimated that energy efficiency improvements in Russia's district heating sector, alone, could save 30 billion cubic metres per year (bcm/yr) to $50 \mathrm{bcm} / \mathrm{yr}$ of natural gas (IEA, 2004). Optimisation of its transmission and distribution systems for natural gas, coupled with reductions in gas flaring by its oil and gas industry, could save up to a further $30 \mathrm{bcm} / \mathrm{yr}$. In the industry sector, the energy savings from the application of best available technologies is estimated at 750 petajoules (PJ). ${ }^{3}$

\footnotetext{
${ }^{1}$ The $\mathrm{G} 8$ countries include Canada, France, Germany, Italy, Japan, Russia, the United Kingdom and the United States.

2 The main energy-consuming sectors typically analysed include industry, residential, service and transport.

${ }^{3}$ It is important to note that this potential cannot be achieved in the short term. The rate of implementation of best available technologies in practice depends on a number of factors, including capital stock turnover, relative energy costs, raw material availability, rates of return on investment and regulations.
} 
Russia, recognising the benefits of more efficient use of energy, is taking measures to exploit this potential. The president has set the goal to reduce energy intensity by $40 \%$ between 2007 and 2020 . Furthermore, since 2008, Russia has taken important steps toward creating a legal and institutional framework to enhance efficient energy use and supply. A law on energy efficiency, passed in the Duma $^{4}$ in November 2009, introduces several important measures such as: restrictions on the sale of incandescent light bulbs; requirements for electrical products to be labelled according to their energy efficiency rating; provisions on mandatory commercial inventories of energy resources; new energy efficiency standards for new buildings and installations; and reductions in budget spending on purchasing energy resources. In addition, energy-intensive businesses will be required to carry out energy-saving research and to adhere to energy-saving and energy-efficiency programmes. This new protocol will also encompass a transition to a long-term tariff regulation and the establishment of a shared inter-ministerial energy efficiency information and analysis system.

In the past few years, the IEA worked closely with Russia's Federal State Statistics Service (Rosstat) and the newly formed Russian Energy Agency to support the development of energy efficiency indicators in Russia. This work, which has focused on the industrial, residential and transport sectors, is critical to an effective implementation and monitoring of Russia's ambitious energy intensity and efficiency goals. Since 2008, the IEA has been working with Rosstat to establish what data already exists, identify the data gaps, and assess the data quality.

The key findings of the IEA work with Russia on developing energy efficiency indicators form the core of this report. The report provides an overall assessment of recent trends, the current data situation in Russia, a list of the basic data needed to develop indicators, and the usefulness and limitation of some key indicators. It comprises five chapters covering the five main end-use sectors: industry, residential, services, passenger transport and freight transport.

The report also includes two methodological annexes. Annex A describes the IEA indicator approach, which uses the idea of a pyramid to portray the hierarchy of energy indicators (from most detailed to least detailed). Annex B includes the IEA energy methodology to analyse trends in energy consumption.

\section{The data situation in Russia to develop indicators}

\section{Industry sector}

The IEA has found that for industry, the data available from Rosstat national energy surveys and Russian National Accounts ${ }^{5}$ are at a detailed enough level of disaggregation to calculate energy indicators based on physical units on production and provide an initial assessment of the effect of energy efficiency on industry energy consumption. However, several major issues still need to be overcome to develop energy efficiency indicators. For instance, Rosstat uses current Russian roubles in its value-added calculations, but in order to establish an overall indicator for the industry sector, value added in constant currency is required. ${ }^{6}$ The IEA is currently working with Rosstat to address this data issue. Questions also exist regarding breaks in Rosstat time series for some data points. More difficult issues remain in relation to defining the coverage of energy consumption data (the boundaries for the industry). The boundaries issues will take much longer to resolve and will demand

\footnotetext{
${ }^{4}$ Russia's parliament.

${ }^{5}$ The National Accounts is a consistent and integrated set of macroeconomic accounts, balance sheets and tables based on a set on internationally agreed concepts, definitions, classifications and accounting rules. It includes data such as GDP, investment, private consumption and level of government debt.

${ }^{6}$ Value added is the difference between output and intermediate consumption for any given sector/industry - that is the difference between the value of goods and services produced and the cost of raw materials and other inputs used in production.
} 
close collaboration with Rosstat experts and statisticians. More detailed analysis will also be needed to better understand Rosstat's industry energy consumption data.

\section{Residential sector}

Some of the necessary data to establish aggregate energy indicators for the residential sector are available for Russia from national annual surveys undertaken by Rosstat. These data include floor area, number of households and source of space heating. New questions added to Rosstat's National Household Income Survey 2010 will start to provide data required to build energy efficiency indicators. The survey will collect information on the stock, age and energy efficiency ranking of large household appliances, as well as on the type of light bulbs used. The national survey will provide data for 2010 and beyond for these new data points, critical for a better understanding of trends in energy consumption of appliances. This national survey will also continue to collect data on the size of dwelling and heated floor area, year of construction and type of heating equipment.

While the expansion of the survey is a positive step in developing an end-use energy database and assessing trends in residential energy and energy efficiency, additional data collection is required for other end-uses such as space heating and cooling, water heating and small appliances.

\section{Service sector}

Services is clearly the most difficult sector in which to collect data. At present, there is a serious lack of detailed data in Russia, making it difficult to analyse trends in service energy consumption. Russia is not unique in this regard; most IEA member countries lack detailed end-use data for the sector. Available data in IEA member countries show that the potential for energy savings in the service sector varies widely for different end-uses. As such, in-depth analysis at the end-use level is needed to develop indicators that can help to define the most important potential for energy efficiency improvements and support the development of relevant policies.

\section{Transport sector}

Much more work is needed in Russia to understand the structure and trends of energy consumption in the transport sector. Analysis of trends in energy and energy efficiency require a separate analysis for passenger and freight transport, as each is influenced by different underlying factors. In Russia, the necessary disaggregated data are not available for energy consumption, and activity data are only available for some transport modes.

Many data sources exists beyond official Rosstat transport sector data, which can go a long way to completing the picture of structure and trends of energy consumption - especially in terms of individual automotive transport, one of the fastest-growing sectors in IEA member countries and likely in Russia, too. Car registration and the annual car inspection process could provide an effective way to enhance the data on driving trends and automotive stock. Given these systems are already in place to gather this important input data, all that may be needed is a co-ordinating body or agency to set up a data collection system. Data estimates and models are also available from various research institutes. The IEA had very useful discussions and preliminary exchange of information with the Scientific and Research Institute of Motor Transport (NIIAT) in Moscow. 


\section{Introduction: the use of indicators to unravel the complexity of energy consumption}

Governments are uniquely positioned to establish, through policy implementation, the

Page | 10 frameworks within which energy is both produced and consumed across many socio-economic levels. As governments around the world tackle the complex and intertwined challenges of improving energy security and reducing greenhouse-gas (GHG) emissions associated with energy production and consumption - while also supporting economic development objectives - two things are increasingly clear:

- Ensuring a better use of the world's energy resources will require policies that encompass a wide range of options. Analysis shows that improving energy efficiency is often the most costeffective, proven and readily available means of achieving this goal.

- Good quality, timely, comparable and detailed data that go well beyond those currently included in statistical energy balances, are necessary to establish and maintain sound policy. These data must reflect the distinct characteristics of economic activity and resources available in each country.

For the overall economy, aggregate indicators such as total primary energy supply (TPES) and total final energy consumption (TFC) per GDP is often used to construct a "big picture" of current patterns of energy use. Aggregate energy indicators have the advantage that they are often readily and widely available. Thus, they can reveal high-level developments in energy use and can be constructed to facilitate basic cross-country comparisons. However, they could often be misleading and consequently it would be incorrect, to rank energy efficiency performance according to a country's TPES or TFC per GDP.

In order to develop estimates of overall energy efficiency, detailed data are required for the main end-use sectors (industry, residential, services and transport). As each sector is influenced by different underlying factors, different explanatory data will be needed depending on the sector analysed. Recent efforts by several countries to collect more detailed end-use data have helped in developing indicators that can be used to understand past trends, assess potential for energy savings and enhance energy efficiency policies.

Understand past trends: Energy balance data for a group of 11 IEA member countries ${ }^{7}$ show that energy consumption increased by $22 \%$ from 1973 to 2006. More importantly, detailed end-use data available for these 11 countries demonstrate that without improvement in energy efficiency over the same period, energy consumption would have been 63\% higher in 2006.

Assess potential for energy savings: Detailed end-use data and indicators are equally essential for assessing the further contribution of energy efficiency. IEA estimates show that large potentials remain across all sectors of the economy.

Enhance energy efficiency policies: This capacity to track trends and identify potential savings makes detailed end-use data and energy efficiency indicators key to launching and monitoring more effective energy efficiency policy.

An analysis of the impacts to date of energy efficiency policies implemented by IEA member countries reveals that effective policies do make a difference. In each of the main energyconsuming sectors, there is evidence of improved efficiency, most of which also results in reduced

\footnotetext{
${ }^{7}$ Australia, Denmark, Finland, France, Germany, Italy, Japan, Norway, Sweden, the United Kingdom and the United States.
} 
carbon dioxide $\left(\mathrm{CO}_{2}\right)$ emissions. In some cases, however, unexpected changes in consumption patterns within a given sector or sub-sector reduce the overall impact of efficiency gains.

Box 1. The IEA energy efficiency indicators template

To facilitate the reporting of comparable data across all IEA member countries, the IEA has worked with the ODYSSEE Network (European Union) and the Asia-Pacific Economic Cooperation (APEC) to develop a standard energy efficiency indicators template. The template (which is similar to - and builds on the success of - the IEA annual energy statistics questionnaires of fuels) establishes uniform system boundaries, data definitions and methodologies specific to energy consumption and other data related to energy efficiency.

Early use of this template by member countries has already allowed the IEA Secretariat to define a series of disaggregate energy indicators that aim to capture key data relevant to each major sector. Generally, these disaggregate indicators probe deeper than energy balances by focusing on activity levels, structural effects, energy efficiency trends and potential for future energy savings.

Such indicators provide a much more effective means of tracking the evolution of energy use within a country and conducting comparative analyses. They can help to identify emerging trends in end-use sectors - including the factors behind increasing energy consumption and those that restrain it. They also help to uncover areas that hold the greatest potential for improving energy efficiency and the overall scope for further energy savings. Ultimately, indicators can thus be used to shape priorities for future actions and to monitor progress.

While it is clear energy efficiency policies work, the fact is that currently available energy data are a poor foundation for developing an in-depth understanding of how or why - or indeed, for analysing which measures are most effective and warrant broader implementation. This fact underlines the reality that existing data and information are too sparse to precisely analyse the impact of specific measures.

Clearly, more data - and different kind of data - are needed to support the strategic development, implementation and evaluation of energy efficiency policies.

This paper examines various energy and energy efficiency indicators - their usefulness and limitations - and describes:

- The set of data needed to calculate key energy and energy efficiency indicators;

- Available data in IEA member countries and in Russia from this set of data; and

- What energy and energy efficiency indicators can be derived with this set of data, and what those indicators reveal. 


\section{Industry sector}

The industry sector covers the manufacturing sector (the manufacture of finished goods and products), mining and quarrying of raw materials and construction. Power generation, refineries and the distribution of electricity, gas and water are excluded from the industry sector.

Russia's industrial sector is vast, including major enterprises in mining, energy, automotive, defence, construction, communication, consumer durables, construction equipment and textiles. But Russia's legacy of its Soviet past is the dominance of heavy industry such as iron and steel, petrochemicals and aluminium - all energy resource intensive. After having been set back by the global economic crisis of 2008, Russian industrial production grew an estimated $11 \%$ in 2009 . Industrial output in Russia rose by $7.8 \%$ in January 2010, a sign that economic recovery was strengthening in Russia. While the production of consumer goods remained flat or increased marginally, production of cars and trains witnessed severe setbacks compared to 2008-09 levels.

Because of its Soviet legacy, Russian industry needs to restructure, streamline costs and ensure that its products meet demand in the most economic and environmentally sound way. The handful of energy efficiency success stories in Russia's industrial sector illustrates how competitive forces spur this on relative to regulate monopolistic markets. Russian industry is slow in realising its energy efficiency potential primarily due to a lack of awareness among managers and insufficient supply of long-term capital to finance energy efficient modernisation (World Bank, 2008). Russia is one of the country with the largest energy savings potential for the five most energy intensive industry (iron and steel, cement, chemicals and petrochemicals, aluminium and pulp and paper) (IEA, 2008; IEA, 2009; IEA 2010). In addition, companies in several sectors lack the incentive to save energy because product prices are growing faster than energy tariffs. In this regard, the continuation of electricity and gas sector reforms are critical to achieving this sector's energy efficiency potential.

Box 2. Energy efficiency trends in manufacturing sector

Globally, energy consumption in the manufacturing sector increased by $29 \%$ between 1990 and $2008 .^{8}$ In 2008 , it accounted for $29 \%$ of TFC and $37 \%$ of end-use sectors $\mathrm{CO}_{2}$ emissions. In Russia, manufacturing energy consumption decreased by about 29\% between 1993 and 2008, while energy consumption in the five most energy-intensive industries decreased only by $2 \%$.

An analysis of the manufacturing sector for 21 IEA member countries ${ }^{9}$ indicates that buoyant economic growth and high energy prices have played a role in improving energy efficiency. In order to satisfy increased demand for commodities, countries added new, more efficient capacity, thereby reducing the share of smaller, less efficient production units. Energy consumption in those 21 IEA member countries would have been $29 \%$ higher in 2006 than it was without the energy efficiency improvements in the sector since 1990.

Despite the impressive recent efficiency gains in IEA member countries, the manufacturing sector still shows considerable potential for further energy savings. The estimated global savings for the five most energy-intensive manufacturing sectors (pulp and paper, chemicals and petrochemicals, iron and steel, aluminium, and cement) are 15 PJ per year - enough to meet the annual energy needs of industry, transport and households in Russia.

\footnotetext{
${ }^{8}$ Fuel-processing industries and fuels used as feedstock are not included in the analysis.

9 IEA 21 includes Australia, Austria, Belgium, Canada, Denmark, Finland, France, Germany, Greece, Italy, Japan, Korea, the Netherlands, New Zealand, Norway, Portugal, Spain, Sweden, Switzerland, United Kingdom and the United States.
} 


\section{Availability of industry data in Russia to develop indicators}

To effectively assess the developments in energy efficiency trends, the impact of energy efficiency measures and the further potential for energy savings in the industry sector, the following data are required:

- Detailed energy consumption data by industry;

- Value-added data in constant currency; and

- Physical production of key commodities, where possible.

While energy consumption data are usually available from the energy balances of countries (although only at the two-digit International Standard Industrial Classification [ISIC] level), valueadded data are not always available (or are available but not for the same level of detail as the data for energy consumption). Value added in constant currency by industry allows the development of indicators for heterogeneous industry, and are required to aggregate the detailed indicators to assess energy efficiency for the total industry sector.

Box 3. Impact of industrial structure

The value-added data by industry are also required to analyse the impact of structural changes in the sector. This information is essential when trying to understand trends in energy consumption, or when performing country comparisons.

Analysis shows that IEA member countries with high shares of energy-intensive industries (such as cement and iron and steel) usually rank among the most intensive countries. However, if those countries had the same structure as the average IEA countries, the aggregate manufacturing intensity would be reduced considerably; by over $20 \%$ in many cases.

In Russia, Rosstat has been collecting for numerous years industry-related data. Rosstat's 11 TER Form (Rosstat energy consumption questionnaire for industry) provides energy consumption at the four-digit ISIC level as well as the production in physical units for the same industrial breakdown. These data are available on an annual basis at both regional and national levels. The information from the 11 TER Form can be used to develop industry-specific indicators, and provide a proxy for the evolution of energy efficiency. The long time series available allows analysis of the evolution of energy efficiency at a detailed level of sectoral disaggregation. However, these multiple indicators do not provide an industry-wide assessment of how energy efficiency in each industry sector influenced the trends in energy consumption for the overall industry.

Physical units of production are the preferred activity variable to build detailed industry indicators. However, for an overall energy efficiency indicator for the industry sector as a whole, aggregation of the various industry-specific indicators is required. Given that physical units of production cannot be added together (one tonne of steel cannot be added to one tonne of clinker), a value-added approach is used from each subsector to provide a common basis.

In doing so, it is essential to use value added in constant currency to avoid including a bias induced by fluctuations on the monetary market. Value added, in current currency, are available from Rosstat's National Accounts at the four-digit ISIC level. However, the deflator to convert the current values to constant ones is only available for the mining, manufacturing and construction sectors. Deflators for the different manufacturing sectors are not available.

The energy consumption data from Rosstat's Form 11 TER and the value added from the National Accounts, if develop in constant roubles, would allow the development of an overall energy 
efficiency indicators for industry. However, the quality and comparability of the data, and the boundaries of each industry, still need to be validated.

For the industry sector, the IEA energy efficiency indicators template requires three elements: energy consumption data (at the two-digit ISIC level and by energy sources); value added in constant currency (two-digit ISIC level); and physical units of production for heterogeneous industry. These represent the

Page | 14 minimum level of information required to develop meaningful energy and energy efficiency indicators.

Box 4. The benefits of energy efficiency indicators for companies

Experience in IEA member countries suggests that industry itself may be very interested in relevant energy efficiency indicators. Companies can use such indicators to draw lessons on how to become more energy efficient, and can benchmark themselves against other companies or chart their own progress over time. Ultimately, indicators can be used to increase competitiveness. With increasing tariffs for Russian domestic electricity and natural gas, more cost-reflective pricing will encourage more energy efficient behaviour - which, in turn, raises net revenues. Further stimulus for energy efficiency through national programmes could bring added incentives to industry: if shareholders view improved efficiency as supporting national goals, the company may see its share price increase.

Collecting data relating to energy use by small- and medium-sized enterprises (SMEs) is not yet a practice in Russia as the underlying legislation for mandatory reporting does not exist. IEA experience is that data from SMEs are an important component of the energy scene. In some IEA countries, SMEs report relevant data on a voluntary basis (in other countries, reporting is mandatory). The IEA also finds that is it often more difficult to collect data from large enterprises: if there are one or two companies in the sector, the enterprises may be averse to reporting due to confidentiality issues.

Industry data IEA member countries are required to report to the IEA through the energy efficiency indicators template, ${ }^{10}$ as well as the number of IEA member countries that currently report such data to the IEA, are presented in Table 1 . The table also shows which data are currently available from Russia.

Table 1: Industry data needed to develop basic energy and energy efficiency indicators

\begin{tabular}{|l|c|c|c|c|c|c|}
\hline $\begin{array}{l}\text { Data needed to develop } \\
\text { indicators }\end{array}$ & \multicolumn{3}{|c|}{$\begin{array}{c}\text { Number of IEA member } \\
\text { countries reporting the data }\end{array}$} & \multicolumn{2}{|c|}{ Data available from Russia } \\
\hline $\begin{array}{c}\text { Energy } \\
\text { use }\end{array}$ & $\begin{array}{c}\text { Value } \\
\text { added }\end{array}$ & $\begin{array}{c}\text { Commodity } \\
\text { production }\end{array}$ & Energy use & $\begin{array}{c}\text { Value } \\
\text { added }\end{array}$ & $\begin{array}{c}\text { Commodity } \\
\text { production }\end{array}$ \\
\hline $\begin{array}{l}\text { Agriculture, hunting, fishing and } \\
\text { forestry }\end{array}$ & $\mathbf{2 8}$ & $\mathbf{2 5}$ & n.a. & Yes & No & n.a. \\
\hline Mining and quarrying & $\mathbf{2 8}$ & $\mathbf{2 4}$ & n.a. & Yes & No & n.a. \\
\hline $\begin{array}{l}\text { Manufacture of coke, refined } \\
\text { petroleum products and nuclear } \\
\text { fuel }\end{array}$ & $\mathbf{2 8}$ & $\mathbf{1 8}$ & n.a. & Yes & No & n.a. \\
\hline Manufacturing & $\mathbf{2 8}$ & $\mathbf{2 6}$ & n.a. & Yes & No & n.a. \\
\hline $\begin{array}{l}\text { Food products, beverages and } \\
\text { tobacco products }\end{array}$ & 28 & 24 & n.a. & Yes & No & n.a. \\
\hline $\begin{array}{l}\text { Textiles, wearing apparel, fur } \\
\text { and leather }\end{array}$ & 26 & 24 & n.a. & Yes & No & n.a. \\
\hline $\begin{array}{l}\text { Wood and of products of wood } \\
\text { and cork, except furniture }\end{array}$ & 24 & 22 & n.a. & Yes & No & n.a. \\
\hline
\end{tabular}

\footnotetext{
${ }^{10}$ For each industry sector, energy use data are also required by energy source.
} 


\begin{tabular}{|c|c|c|c|c|c|c|}
\hline \multirow[t]{2}{*}{$\begin{array}{l}\text { Data needed to develop } \\
\text { indicators }\end{array}$} & \multicolumn{3}{|c|}{$\begin{array}{l}\text { Number of IEA member } \\
\text { countries reporting the data }\end{array}$} & \multicolumn{3}{|c|}{ Data available from Russia } \\
\hline & $\begin{array}{l}\text { Energy } \\
\text { use }\end{array}$ & $\begin{array}{l}\text { Value } \\
\text { added }\end{array}$ & $\begin{array}{l}\text { Commodity } \\
\text { production }\end{array}$ & Energy use & $\begin{array}{l}\text { Value } \\
\text { added }\end{array}$ & $\begin{array}{l}\text { Commodity } \\
\text { production }\end{array}$ \\
\hline Paper and paper products & 27 & 17 & n.a. & Yes & No & n.a. \\
\hline Pulp & 0 & 0 & 28 & Yes & No & Yes \\
\hline Paper & 0 & 0 & 28 & Yes & No & Yes \\
\hline $\begin{array}{l}\text { Publishing, printing and } \\
\text { reproduction of recorded media }\end{array}$ & 8 & 18 & n.a. & Yes & No & n.a. \\
\hline $\begin{array}{l}\text { Chemicals and chemical } \\
\text { products }\end{array}$ & 28 & 24 & n.a. & Yes & No & n.a. \\
\hline Rubber and plastics products & 14 & 24 & n.a. & Yes & No & n.a. \\
\hline Non-metallic mineral products & 28 & 25 & n.a. & Yes & No & n.a. \\
\hline Cement & 10 & 0 & 28 & Yes & No & Yes \\
\hline Clinker & 0 & 0 & 0 & Yes & No & Yes \\
\hline Basic metals & 28 & 23 & n.a. & Yes & No & n.a. \\
\hline Casting of iron and steel & 28 & 0 & 28 & Yes & No & Yes \\
\hline $\begin{array}{l}\text { Casting of precious and non- } \\
\text { ferrous metals }\end{array}$ & 0 & 0 & n.a. & Yes & No & n.a. \\
\hline Aluminium & 0 & 0 & 0 & Yes & No & No? \\
\hline $\begin{array}{l}\text { Motor vehicles and other } \\
\text { transportation equipment }\end{array}$ & 23 & 23 & n.a. & Yes & No & n.a. \\
\hline Other manufacturing & 28 & 21 & n.a. & Yes & No & n.a. \\
\hline
\end{tabular}

Notes: n.a. = not applicable as the sector as defined in the table is too heterogeneous to have a single measure of physical production. IEA countries coverage indicates the number of IEA member countries for which data are currently available from 1990 to 2006 in the energy indicators database. As the IEA has not yet received value-added data in constant currency, the value-added data are indicated as not being available from Russia. Coverage for Russia is based on IEA knowledge of the data situation in Russia for 2000 onward; these have been validated by Rosstat.

\section{Key indicators for the industrial sector}

Information collected through the IEA energy efficiency indicators template is used to develop energy and energy efficiency indicators that explain the changes in energy consumption over a period of time. Key energy and energy efficiency indicators that can be developed with the data collected through the template, as well as the purpose and limitation of those indicators, are presented in Table 2.

More detailed indicators can be built by collecting information at the process level for each subindustry and facility characteristics. However, such data are available only for very few countries and for a limited number of sub-industries.

It is also possible to couple the information on energy consumption with data on energy prices in manufacturing, energy expenditures and capacity production to analyse the impact of these factors on the trends in energy consumption.

In some manufacturing sectors, portion of the energy consumption is influenced by weather conditions. The influence on energy consumption is different from industry to industry. Given the very limited information available on the impact of weather in industry, and the lack of internationally recognised methodology to perform such an adjustment in the industry, the IEA methodology does not take into account weather conditions in analysing the manufacturing sector. 
Table 2: Key indicators to understand trends in energy and energy efficiency in industry

\begin{tabular}{|c|c|c|c|c|}
\hline & Indicator & Data required & Purpose & Limitation \\
\hline \multirow{4}{*}{ 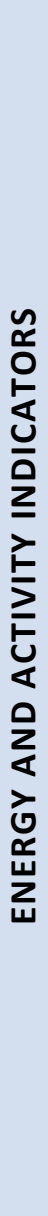 } & $\begin{array}{l}\text { Total industry energy } \\
\text { consumption by } \\
\text { energy source }\end{array}$ & $\begin{array}{l}\text { Total industry energy } \\
\text { consumption by } \\
\text { energy source. }\end{array}$ & $\begin{array}{l}\text { Insights on the role of the final energy } \\
\text { mix on total final energy consumption. } \\
\text { Insights on the trends in } \mathrm{CO}_{2} \\
\text { emissions. }\end{array}$ & $\begin{array}{l}\text { - Observed energy trends not necessarily a result of improved } \\
\text { (or worsening) energy efficiency. } \\
\text { - One element, amongst many others, influencing trends in } \\
\text { energy consumption. } \\
\text { industry structure and processes and implementation of } \\
\text { environmental legislation that favours the use of cleaner fuels. }\end{array}$ \\
\hline & $\begin{array}{l}\text { Energy consumption } \\
\text { by industry sectors } \\
\text { and by energy source }\end{array}$ & $\begin{array}{l}\text { Energy consumption } \\
\text { by industry sectors } \\
\text { and by energy } \\
\text { source. }\end{array}$ & $\begin{array}{l}\text { - Explain the role energy mix played on } \\
\text { the trend in energy consumption in } \\
\text { each industry. } \\
\text { - Insights on the trends in } \mathrm{CO}_{2} \\
\text { emissions. } \\
\text { - Not influenced by industry structure } \\
\text { when developed at a very } \\
\text { disaggregated level. }\end{array}$ & $\begin{array}{l}\text { - Observed energy trends not necessarily a result of improved } \\
\text { (or worsening) energy efficiency. } \\
\text { - Influenced by changes in relative fuel prices, shifts in } \\
\text { industry processes and implementation of environmental } \\
\text { legislation. } \\
\text { - Influenced by industry structure if develop at an aggregate } \\
\text { level (e.g. two digits ISIC). }\end{array}$ \\
\hline & $\begin{array}{l}\text { Composition of } \\
\text { industry value added } \\
\text { (in constant currency) }\end{array}$ & $\begin{array}{l}\text { Value added in } \\
\text { constant currency by } \\
\text { industry sector at the } \\
\text { two-digit ISIC level } \\
\text { (or more detail). }\end{array}$ & $\begin{array}{l}\text { Provide information on the relative } \\
\text { importance of each sector. } \\
\text { Insights of the impact of the structure } \\
\text { of the industry on energy } \\
\text { consumption. } \\
\text { Qualitative information helping to } \\
\text { explain trends in energy consumption. }\end{array}$ & $\begin{array}{l}\text { Value added is influenced by a range of pricing effects } \\
\text { unrelated to changes in the level of physical production. } \\
\text { - Composition of industry value added, at two-digit ISIC level, } \\
\text { industry sector. } \\
\text { Does not provide the link between value added and energy } \\
\text { required to quantify the impact of the structural change. }\end{array}$ \\
\hline & $\begin{array}{l}\text { Total industry energy } \\
\text { consumption by unit } \\
\text { of value added }\end{array}$ & $\begin{array}{l}\text { Total industry energy } \\
\text { use. } \\
\text { Total industry value } \\
\text { added (in constant } \\
\text { currency). }\end{array}$ & $\begin{array}{l}\text { Reflects the trends in overall energy } \\
\text { use relative to value added. } \\
\text { Indicates the general relationship of } \\
\text { energy use to economic development. }\end{array}$ & $\begin{array}{l}\text { - Influenced by factors such as geography, climate and } \\
\text { structure of the economy. } \\
\text { - Changes over time are influenced by factors not necessarily } \\
\text { related to energy efficiency. }\end{array}$ \\
\hline
\end{tabular}




\begin{tabular}{|c|c|c|c|c|}
\hline & Indicator & Data required & Purpose & Limitation \\
\hline 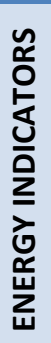 & $\begin{array}{l}\text { Industry sectors } \\
\text { energy consumption } \\
\text { by unit of value added }\end{array}$ & $\begin{array}{l}\text { Energy consumption } \\
\text { by industry sector. } \\
\text { Corresponding value } \\
\text { added (in constant } \\
\text { currency). }\end{array}$ & $\begin{array}{l}\text { Indicate the general relationship of } \\
\text { energy use to economic development. }\end{array}$ & $\begin{array}{l}\text { May hide some important structural shift within an industry } \\
\text { (but this impact will be somewhat offset by using more } \\
\text { detailed energy and value added data). } \\
\text { Value added are influenced by a range of pricing effects that } \\
\text { are unrelated to changes in the underlying physical } \\
\text { production. }\end{array}$ \\
\hline \multirow{2}{*}{ 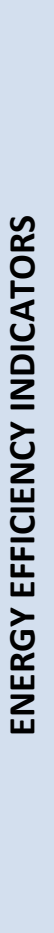 } & $\begin{array}{l}\text { Industry sector energy } \\
\text { use by unit of physical } \\
\text { production }\end{array}$ & $\begin{array}{l}\text { - Energy consumption } \\
\text { by industry sector. } \\
\text { Corresponding } \\
\text { physical unit of } \\
\text { production. }\end{array}$ & $\begin{array}{l}\text { - Often called the "specific" or "unit } \\
\text { energy" consumption. } \\
\text { - Indicate the relationship of energy use } \\
\text { to physical production. } \\
\text { - At the disaggregated level, can give a } \\
\text { better measure of the technical } \\
\text { efficiency of a particular production } \\
\text { process. }\end{array}$ & $\begin{array}{l}\text { It is not possible to compare indicators defined in differing } \\
\text { units. } \\
\text { - Cannot provide an aggregate picture of energy efficiency for } \\
\text { the whole of industry. }\end{array}$ \\
\hline & $\begin{array}{l}\text { Decomposition of } \\
\text { changes in industry } \\
\text { energy consumption }\end{array}$ & $\begin{array}{l}\text { Energy consumption } \\
\text { by industry sector } \\
\text { and energy source. } \\
\text { Corresponding } \\
\text { physical unit of } \\
\text { production (if } \\
\text { available). } \\
\text { Corresponding value } \\
\text { added (in constant } \\
\text { currency). }\end{array}$ & $\begin{array}{l}\text { Quantification of the factors } \\
\text { underlying the changes in energy } \\
\text { consumption over a defined period of } \\
\text { time. } \\
\text { Changes in energy consumption are } \\
\text { decomposed between industry } \\
\text { structure effect, energy mix effect, } \\
\text { and specific intensity effect (a proxy of } \\
\text { energy efficiency). } \\
\text { This is the best indicator for total } \\
\text { industry that can be developed with } \\
\text { the data required in the IEA energy } \\
\text { efficiency indicators template. }\end{array}$ & $\begin{array}{l}\text { This proxy for energy efficiency still includes effects that are } \\
\text { not related to technical efficiency (such as the impact of } \\
\text { climatic conditions and the change in the processes used } \\
\text { within a facility). }\end{array}$ \\
\hline
\end{tabular}




\section{Residential sector}

The residential sector includes those activities related to private dwellings. It covers all energyusing activities in apartments and houses, including space and water heating, cooling, lighting and the use of appliances. It does not include personal transport, which is covered in the Page | 18 transport sector.

Between 1993 and 2004, residential energy consumption in Russia was greater than for the industry sector, as is typical for lower-income countries in harsh climates. However, in 2005 the commercial energy consumption data appear to have been readjusted upward, and resulted in a dramatic reduction in energy consumption in the residential sector. As a result, in 2005, Russian TFC in the industrial sector (5 $169 \mathrm{PJ}$ ) surpassed that of the residential sector (4 $628 \mathrm{PJ}$ ). Following this reduction, according to IEA data based on annual submissions from Rosstat, residential consumption has remained relatively flat over the 2005 to 2008 period.

On a per-capita basis, residential energy consumption roughly equals that in Canada, even though Canada has three times Russia's per capita floor space and electric appliances are larger and more widespread. Thus, Russian residential energy consumption is at least two-to-three times more energy intensive than Canada's. The reasons are known: lack of consumer control over heat regulation, low share of private ownership of apartments (landlords usually having little interest in investing in energy efficiency improvements) and price subsidies. Large potential for energy savings exists in the residential sector. A study from the IEA estimated that energy efficiency improvements in Russia's district heating sector could save $30 \mathrm{bcm} / \mathrm{yr}$ to $50 \mathrm{bcm} / \mathrm{yr}$ of natural gas (IEA, 2004).

The most significant barriers to energy efficiency in residential housing relate to building standards, public behaviour and difficulties in organising and financing energy efficiency improvements in common areas (World Bank 2008).

Box 5. Energy efficiency trends in residential sector

Globally, residential energy consumption increased by 20\% between 1990 and 2006; it accounted for $28 \%$ of TFC in 2006 and $20 \%$ of end-use sectors $\mathrm{CO}_{2}$ emissions. In Russia, residential energy consumption decreased by 32\% between 1993 and 2006, and accounted for 26\% of TFC in 2006.

Detailed end-use data for the residential sector are available for 19 IEA member countries, ${ }^{11}$ allowing a deeper analysis of the factors influencing residential trends in energy consumption. The analysis indicates that the low growth in energy requirements for space heating per capita reflects an impressive $19 \%$ improvement in energy efficiency. In fact, efficiency improvements offset most of the increase in energy consumption arising from trends toward larger dwelling sizes and fewer occupants per dwelling.

The analysis also reveals a significant shift in appliances energy consumption. The share of large appliances (e.g., refrigerators, freezers, dishwashers and clothes washers) in total appliance energy consumption dropped from $47 \%$ in 1990 to only $28 \%$ in 2006. Increasing ownership of a wide range of small appliances (e.g. personal computers and mobile phones) was the key factor driving the rise in residential electricity consumption - which is up by $41 \%$.

Overall, residential energy consumption in these 19 IEA member countries increased by $15 \%$ since 1990; almost half of this increase was due to the growth in energy consumption of appliances.

\footnotetext{
${ }^{11}$ IEA 19 includes Australia, Austria, Canada, Denmark, Finland, France, Germany, Ireland, Italy, Japan, Korea, the Netherlands, New Zealand, Norway, Spain, Sweden, Switzerland, the United Kingdom, the United States.
} 


\section{Availability of residential data in Russia to develop indicators}

Total residential energy consumption, by energy source, is available from energy balances. As each end-use is influenced by different factors, the analysis of energy efficiency trends in the residential sector requires, at a minimum, detailed information at the end-use level, and associated activity data. Furthermore, as space heating is greatly influenced by climatic conditions, notably in countries with cold climates such as Russia, an adjustment is required to account for the yearly variation in weather conditions.

For developing policy-relevant indicators in the residential sector, the following data are required:

- energy consumption by major end-uses and by energy sources;

- main activity variables for the sector, including number of households and residential floor area;

- information on the stock and efficiency not only of large appliances, but also of small appliances given their growing importance; and

- information on heating and cooling degree-days to adjust for weather conditions.

Some activity data are available for Russia from Rosstat's National Households Income Survey on an annual basis for several decades. These include number of houses and floor area by dwelling type and year of construction, heated floor area and type of heating system. The survey also collects information on the access of households to the electricity and gas grid, and if dwellings are connected to the district heating system or have individual heating devices (and which energy source is used).

The IEA is encouraged by the new questions Rosstat included in its annual Household Budget Survey. Starting in 2011, the survey will include questions on: additional heat sources used by households; metering devices; number and type of light bulbs; number of appliances and year of acquisition; efficiency ranking; and class of large appliances. The survey, which will be conducted in 2011, will provide data for 2010 and beyond for these new data points.

Despite these positive developments, the minimal set of data required to develop energy efficiency indicators is not available for Russia. More information, at the end-use level, is necessary.

Box 6. Determining priority area for developing end-use data

Even in IEA member countries, developing the data for each end-use is a challenge and can be resource intensive (both in term of human and financial resources). The development of basic indicators can help to identify which end-use should be a priority for energy efficiency initiatives and policies in the residential sector and where to start in terms of data collection strategy. Once priority areas are determined, efforts should first concentrate on these end-uses. For example, if space heating is a priority area, then supplementary information (such as type of heating device, insulation of houses, age of capital stock and efficiency rating of heating equipment) could be collected to develop in-depth indicators, allowing the development of targeted actions.

Data that IEA member countries are required to report to the IEA through the energy efficiency indicators template, as well as the number of countries that are currently able to provide the data are presented in Table 3. It also presents which data are currently available from Russia. 
Table 3: Residential data needed to develop basic energy and energy efficiency indicators

\begin{tabular}{|c|c|c|}
\hline Data needed to develop indicators & $\begin{array}{l}\text { Number of IEA member } \\
\text { countries reporting the data }\end{array}$ & $\begin{array}{l}\text { Data available } \\
\text { from Russia }\end{array}$ \\
\hline \multicolumn{3}{|l|}{ Energy consumption by: } \\
\hline Energy source & 28 & Yes \\
\hline End-use (and energy source) & 20 & No \\
\hline Space heating & 25 & No \\
\hline Space cooling & 5 & No \\
\hline Water heating & 24 & No \\
\hline Cooking & 23 & No \\
\hline Lighting & 21 & No \\
\hline Appliances & 24 & No \\
\hline Refrigerators & 2 & No \\
\hline Freezers & 12 & No \\
\hline Refrigerator/freezer combinations & 13 & No \\
\hline Dish washers & 13 & No \\
\hline Clothes washers & 14 & No \\
\hline Clothes dryers & 4 & No \\
\hline Television/home entertainment & 13 & No \\
\hline $\begin{array}{l}\text { Personal computers/information and } \\
\text { communication technology }\end{array}$ & 5 & No \\
\hline Other appliances & 24 & No \\
\hline Total dwellings & 27 & Yes \\
\hline Total occupied dwellings & 27 & Yes \\
\hline Total dwelling area & 24 & Yes \\
\hline Stock of appliances & 14 & Yes \\
\hline Refrigerators & 1 & Yes \\
\hline Freezers & 19 & Yes \\
\hline Refrigerator/freezer combinations & 17 & Yes \\
\hline Dishwashers & 15 & Yes \\
\hline Clothes washers & 17 & Yes \\
\hline Clothes dryers & 5 & Yes \\
\hline Television/home entertainment & 13 & Yes \\
\hline PC/information and communication technology & 4 & Yes \\
\hline $\begin{array}{l}\text { Average unit energy consumption of large } \\
\text { appliances stock }\end{array}$ & 13 & No \\
\hline Annual heating degree-days & 27 & No \\
\hline Annual cooling degree-days & 6 & No \\
\hline
\end{tabular}

Note: IEA countries coverage indicates the number of IEA member countries for which data are currently available from 1990 to 2006 in the energy indicators database. Coverage for Russia is based on IEA knowledge of the data situation in Russia; which has been validated by the Russian Federation. 


\section{Key indicators for the residential sector}

The data collected through the IEA energy efficiency indicators template provide a basis to better understand energy consumption trends in the residential sector, identify major trends by end-use and help identify areas for further investigation. Key indicators that can be developed with the set of data collected through the IEA energy efficiency indicator template as well as the purpose and limitation of those energy and energy efficiency indicators are presented in Table 4. For the buildings sector (residential and services), variation in weather conditions may have an important impact on trends and level of energy consumption. If the indicators are developed without taking the climatic conditions into consideration, the trends observed in aggregate indicators may be misleading.

More indicators can be developed by coupling the information on energy use with other data such as dwelling type, personal consumption expenditures, dwellings characteristics, energy expenditures or residential energy prices. 
Table 4: Key indicators to understand trends in energy and energy efficiency in residential

\begin{tabular}{|c|c|c|c|c|}
\hline & Indicator & Data required & Purpose & Limitation \\
\hline \multirow{5}{*}{ 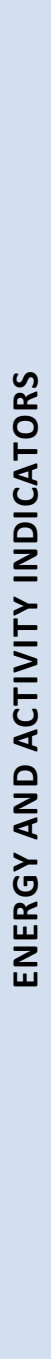 } & $\begin{array}{l}\text { Residential energy consumption by } \\
\text { energy source }\end{array}$ & $\begin{array}{l}\text { Energy } \\
\text { consumption by } \\
\text { energy source. }\end{array}$ & $\begin{array}{l}\text { Insights on the role of the final energy } \\
\text { mix on total final energy consumption. } \\
\text { - Insights on the trends in } \mathrm{CO}_{2} \text { emissions. } \\
\text { Provides qualitative information on which } \\
\text { end-use might have been the fastest } \\
\text { growing or is the most important. }\end{array}$ & $\begin{array}{l}\text { Observed trends in energy not necessarily a } \\
\text { result of improved (or worsening) energy } \\
\text { efficiency. } \\
\text { - One element, among many others, } \\
\text { influencing trends in energy consumption. } \\
\text { Changes can be attributed to increase in the } \\
\text { use of appliances (mostly electricity), } \\
\text { changes in fuel accessibility, replacement of } \\
\text { heating systems and introduction of } \\
\text { regulations and standards. }\end{array}$ \\
\hline & Population per occupied dwelling & $\begin{array}{l}\text { - Population. } \\
\text { Number of } \\
\text { occupied dwelling. }\end{array}$ & $\begin{array}{l}\text { - Occupancy rate is one of the factors } \\
\text { influencing trends in energy consumption } \\
\text { (there is an inverse relationship between } \\
\text { occupancy rates and energy demand). }\end{array}$ & $\begin{array}{l}\text { Provide little information on its own, i.e. if } \\
\text { the decrease results from a decrease in } \\
\text { population, the impact on energy } \\
\text { consumption may be negligible. }\end{array}$ \\
\hline & Average dwelling size & $\begin{array}{l}\text { Total floor area. } \\
\text { Number of } \\
\text { dwellings. }\end{array}$ & $\begin{array}{l}\text { Dwelling area usually has a major impact } \\
\text { on energy consumption for space } \\
\text { heating, lighting and cooling. }\end{array}$ & $\begin{array}{l}\text { Provide useful information only for end-uses } \\
\text { that are impacted by the dwelling area. } \\
\text { - One element, among many others, } \\
\text { influencing trends in energy consumption. }\end{array}$ \\
\hline & $\begin{array}{l}\text { Residential energy consumption by } \\
\text { energy source per capita }\end{array}$ & $\begin{array}{l}\text { Energy } \\
\text { consumption by } \\
\text { energy source. } \\
\text { - Population. }\end{array}$ & $\begin{array}{l}\text { Can be constructed for many countries } \\
\text { and provides a consistent basis for } \\
\text { comparison. } \\
\text { Provides qualitative information on } \\
\text { which end-use might have been the } \\
\text { fastest growing. }\end{array}$ & $\begin{array}{l}\text { The indicator is influenced by the } \\
\text { penetration rate of different appliances, the } \\
\text { number of people per house, the trends in } \\
\text { house size and house type, the efficiency of } \\
\text { water and space cooling devices, the type of } \\
\text { light bulbs used, the efficiency of the } \\
\text { building shell, etc. }\end{array}$ \\
\hline & $\begin{array}{l}\text { Residential energy consumption per } \\
\text { household }\end{array}$ & $\begin{array}{l}\text { Energy } \\
\text { consumption. } \\
\text { Number of } \\
\text { households. }\end{array}$ & $\begin{array}{l}\text { Provides a general overview of the } \\
\text { trends in aggregate energy intensity. } \\
\text { When energy use by end-use is not } \\
\text { known, energy use per household can be }\end{array}$ & $\begin{array}{l}\text { Does not measure energy efficiency } \\
\text { developments. } \\
\text { Influenced by many factors not related to } \\
\text { energy efficiency. }\end{array}$ \\
\hline
\end{tabular}




\begin{tabular}{|c|c|c|c|c|}
\hline & Indicator & Data required & Purpose & Limitation \\
\hline & & & $\begin{array}{l}\text { used as an energy-intensity indicator. } \\
\text { Some important conclusions can be drawn } \\
\text { if the weather, ownership of energy-using } \\
\text { appliances and dwelling area are known. }\end{array}$ & \\
\hline \multirow{4}{*}{ 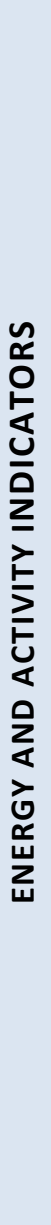 } & $\begin{array}{l}\text { Residential energy consumption per } \\
\text { floor area }\end{array}$ & $\begin{array}{l}\text { Energy } \\
\text { consumption. } \\
\text { Total floor area. }\end{array}$ & $\begin{array}{l}\text { Monitor energy use in the residential } \\
\text { sector. } \\
\text { Combined with energy use per } \\
\text { household, provides useful insights on } \\
\text { what might have been the main driver of } \\
\text { energy consumption. }\end{array}$ & $\begin{array}{l}\text { Does not measure energy efficiency } \\
\text { developments. } \\
\text { - Influenced by many factors not related to } \\
\text { energy efficiency. }\end{array}$ \\
\hline & $\begin{array}{l}\text { Residential energy consumption by } \\
\text { end-use }\end{array}$ & $\begin{array}{l}\text { Energy } \\
\text { consumption by } \\
\text { end-use. }\end{array}$ & $\begin{array}{l}\text { Provide an indication of the trends in } \\
\text { energy consumption and the relative } \\
\text { importance of each end-use. } \\
\text { Provide an indication of priority areas to } \\
\text { further improve data collection or } \\
\text { develop energy efficiency policies. }\end{array}$ & $\begin{array}{l}\text { Provides little information on the impact of } \\
\text { energy efficiency on the trend in energy } \\
\text { consumption by end-use. }\end{array}$ \\
\hline & $\begin{array}{l}\text { Share of large appliances' energy } \\
\text { consumption in total appliance } \\
\text { energy consumption }\end{array}$ & $\begin{array}{l}\text { Large appliances } \\
\text { energy } \\
\text { consumption. } \\
\text { Total appliances } \\
\text { energy } \\
\text { consumption. }\end{array}$ & $\begin{array}{l}\text { Help understand trends in energy } \\
\text { consumption for the appliances end-use. } \\
\text { Provides an indication of which segment } \\
\text { of the appliance market is driving energy } \\
\text { consumption. } \\
\text { Allow the development of more targeted } \\
\text { policies. }\end{array}$ & $\begin{array}{l}\text { Influence by the age of the stock, the } \\
\text { efficiency rating of the new appliances } \\
\text { entering the market and the ownership } \\
\text { level among other. }\end{array}$ \\
\hline & $\begin{array}{l}\text { Residential end-use energy } \\
\text { consumption by floor area or } \\
\text { households }\end{array}$ & $\begin{array}{l}\text { Energy } \\
\text { consumption by } \\
\text { end-use. } \\
\text { Number of } \\
\text { occupied dwellings. } \\
\text { Occupied floor } \\
\text { area. }\end{array}$ & $\begin{array}{l}\text { Related to, but not identical to, the } \\
\text { inverse of energy efficiencies. } \\
\text { - Used as a proxy for energy efficiency in } \\
\text { many countries. }\end{array}$ & $\begin{array}{l}\text { Influenced by many non-efficiency factors } \\
\text { including: type/age of heating equipment, } \\
\text { ownership rate for appliances. }\end{array}$ \\
\hline
\end{tabular}




\begin{tabular}{|c|c|c|c|c|}
\hline & Indicator & Data required & Purpose & Limitation \\
\hline 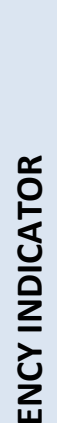 & $\begin{array}{l}\text { Decomposition of changes in energy } \\
\text { use: activity, structure and intensity } \\
\text { effects }\end{array}$ & $\begin{array}{l}\text { Energy } \\
\text { consumption by } \\
\text { end-use. } \\
\text { - Population. } \\
\text { - Dwelling area. } \\
\text { - Appliance } \\
\text { ownership. } \\
\text { - People per } \\
\text { dwelling. }\end{array}$ & $\begin{array}{l}\text { Provide a general understanding of the } \\
\text { trends that influenced change in energy } \\
\text { consumption. } \\
\text { Quantify the role of the activity, } \\
\text { structure and end-use intensities on the } \\
\text { development of energy consumption. }\end{array}$ & $\begin{array}{l}\text { Does not provide how different factors are } \\
\text { impacting on each end-use. }\end{array}$ \\
\hline 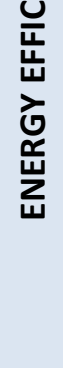 & $\begin{array}{l}\text { Decomposition of changes in space } \\
\text { heating energy use: conversion } \\
\text { efficiency, dwelling size, useful } \\
\text { intensity and occupancy effects }\end{array}$ & $\begin{array}{l}\text { - Space heating } \\
\text { energy } \\
\text { consumption by } \\
\text { energy source. } \\
\text { - Dwelling area. } \\
\text { - People per } \\
\text { dwelling. } \\
\text { - Population. }\end{array}$ & $\begin{array}{l}\text { Allow the quantification of the useful } \\
\text { energy intensity effect on total energy } \\
\text { consumption (a proxy for energy } \\
\text { efficiency). } \\
\text { - This is the best indicator that can be } \\
\text { developed for space heating with the } \\
\text { data required in the IEA energy efficiency } \\
\text { indicators template. }\end{array}$ & $\begin{array}{l}\text { This proxy for energy efficiency still includes } \\
\text { effects that are not related to technical } \\
\text { efficiency such as changes in the mix of } \\
\text { housing type. }\end{array}$ \\
\hline
\end{tabular}




\section{Service sector}

The service sector includes activities related to trade, finance, real estate, public administration, health, education and commercial services.

According to IEA data, energy consumption in Russia's service sector increased over $65 \%$ during the decade between 1998 and 2008. This is largely due to a statistical readjustment in 2005 . Notably, between 2005 and 2008, Russia's energy consumption in the service sector has increased by $17 \%$. Given the strong economic growth Russia experienced until 2008, it is not surprising that its service sector grew so quickly. The global financial crisis also affected Russia, and we can expect a slowdown in energy consumption between 2008 and 2009. If Russian energy efficiency policies are effectively implemented into the future, this will be visible in its service sector.

Box 7. Energy efficiency trends in service sector

Globally, service is, with transport, the fastest-growing sector with an associated $39 \%$ increase in energy consumption between 1990 and 2006. In 2006, services accounted for $9 \%$ of TFC and $12 \%$ of end-use sectors' $\mathrm{CO}_{2}$ emissions. Economic activity is the main driver of energy consumption in the service sector; it is represented by the level of value-added output. In recent years, higher economic activity has led to increases in the stock of commercial buildings and to more people being employed in the sector. Both of these factors increase demand for energy services.

At present, a serious lack of detailed data makes it difficult to analyse trends in service energy consumption in most countries. The data available show a rapid increase in electricity consumption and a corresponding reduction in the share of fossil fuel use.

\section{Availability of service data in Russia to develop indicators}

Energy consumption, by energy sources, is available for the service sector from country's energy balances. The assessment of energy efficiency improvements in the service sector requires, at minimum, data for:

- energy consumption by major end-uses and by energy sources;

- main activity variables for the sector including value-added data in constant currency, floor area and number of employees; and

- information on heating and cooling degree-days to adjust for weather conditions.

Given that detailed value added and employment data are available from Rosstat for the mining and manufacturing sectors, it is possible that this information is also available for the services sector (ISIC 50-99). Deflators are available by service category ${ }^{12}$ from Rosstat National Accounts to convert the value added in current Roubles to constant Roubles. The data situation for the service sector in Russia is at par with most IEA member countries. However, it should be emphasised that, at present, the serious lack of detailed data in this sector across all IEA member countries makes it difficult to analyse trends in service energy consumption.

As the service sector only accounts for $8 \%$ of TFC in Russia, and given the data limitations in the residential and transport sector, the IEA does not think that service should be the priority area for data collection.

\footnotetext{
${ }^{12}$ Bulk and retail trade, maintenance of automobile transport, motorcycles, household goods, and personal items, hotels and restaurants, transport and communications, financial activities, real estate operations, rental and providing services, state governance and defence, social security, education, health care and social services, other municipal, public and personal services.
} 
Data that IEA member countries are required to report through the IEA energy efficiency template, as well as the number of countries that are currently able to provide the data, are presented in Table 5. The information collected is used to develop basic energy indicators to explain the changes in energy consumption over a period of time.

This basic set of data is only a starting point. It would allow the service energy consumption to be adjusted for weather conditions, and would provide a preliminary analysis of the main consuming end-uses. Collecting this information by type of building (health, schools, warehouses, etc.) would support an analysis of the structure of the service sector and allow the development of detailed indicators that would facilitate policy development.

Table 5: Service data needed to develop basic energy and energy efficiency indicators

\begin{tabular}{|c|c|c|}
\hline Data needed to develop indicators & $\begin{array}{c}\text { Number of IEA member } \\
\text { countries reporting the data }\end{array}$ & Data available from Russia \\
\hline Energy consumption by: & 28 & Yes \\
\hline Energy source & 3 & No \\
\hline End-use & 3 & No \\
\hline Space heating (and by energy source) & 3 & No \\
\hline Space cooling & 2 & No \\
\hline Lighting & 3 & No \\
\hline Other (and by energy source) & 27 & Yes \\
\hline Total service floor area & 27 & Yes \\
\hline Floor area addition & 24 & No \\
\hline Number of employees & 14 & No \\
\hline Services value added & 27 & No \\
\hline Annual heating degree-days & 6 & 3 \\
\hline Annual cooling degree-days & & \\
\hline
\end{tabular}

Note: IEA countries coverage indicates the number of IEA member countries for which data are currently available from 1990 to 2006 in the energy indicators database. Coverage for Russia is based on IEA knowledge of the data situation in Russia; which has been validated by the Russian Federation.

\section{Key indicators for the service sector}

In the absence of detailed information on energy consumption, activity and other relevant data, only general indicators can be calculated for the service sector. Some of the key indicators that can be developed with the data reported in the template are presented in Table 6 . The table does not present indicators at the end-use level (which would be similar to those in the residential sector) as only a very limited number of countries can report this information. 
Table 6: Key indicators to understand trends in energy and energy efficiency in services

\begin{tabular}{|c|c|c|c|c|}
\hline & Indicator & Data required & Purpose & Limitation \\
\hline \multirow{4}{*}{ 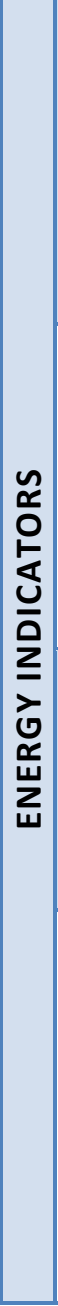 } & $\begin{array}{l}\text { Service energy } \\
\text { consumption by } \\
\text { energy source }\end{array}$ & $\begin{array}{l}\text { Total service } \\
\text { energy } \\
\text { consumption by } \\
\text { energy source. }\end{array}$ & $\begin{array}{l}\text { - Insights on the role of the final energy mix on } \\
\text { total final energy consumption. } \\
\text { - Insights on the trends in } \mathrm{CO}_{2} \text { emissions. } \\
\text { Provide qualitative information indicating which } \\
\text { end-use might have been the fastest growing. }\end{array}$ & $\begin{array}{l}\text { - Observed trends in energy not necessarily a result of } \\
\text { improved (or worsening) energy efficiency. } \\
\text { in energy consumption. } \\
\text { - Can be influenced by increase in the use of office } \\
\text { equipments and space cooling, introduction of regulations } \\
\text { and standards, and relative energy prices. }\end{array}$ \\
\hline & $\begin{array}{l}\text { Service energy } \\
\text { consumption per } \\
\text { services value } \\
\text { added }\end{array}$ & $\begin{array}{l}\text { Total service } \\
\text { energy } \\
\text { consumption. } \\
\text { Total service value } \\
\text { added (in constant } \\
\text { currency). }\end{array}$ & $\begin{array}{l}\text { - Reflect the trends in overall energy use relative to } \\
\text { value added. } \\
\text { - Indicates the general relationship of energy use to } \\
\text { economic development. }\end{array}$ & $\begin{array}{l}\text { Depends on factors such as climate, geography and the } \\
\text { structure of the service sector. } \\
\text { - Influenced by change in services structure. } \\
\text { Different service sector activities can produce very } \\
\text { different levels of economic output. } \\
\text { Value added are influenced by a range of pricing effects } \\
\text { that are unrelated to changes in the energy consumption. }\end{array}$ \\
\hline & $\begin{array}{l}\text { Service energy } \\
\text { consumption by } \\
\text { energy source } \\
\text { per floor area }\end{array}$ & $\begin{array}{l}\text { Total service } \\
\text { energy } \\
\text { consumption by } \\
\text { energy source. } \\
\text { Total service floor } \\
\text { area. }\end{array}$ & $\begin{array}{l}\text { - Combined with the previous indicator, can } \\
\text { provide indications on the nature of the sector } \\
\text { driving energy consumption. } \\
\text { Can provide insights on the end-use driving the } \\
\text { change in energy use. }\end{array}$ & $\begin{array}{l}\text { Depends on factors such as climate, geography and the } \\
\text { structure of the service sector. } \\
\text { - Influenced by change in services structure; different } \\
\text { building types have very different energy requirements. }\end{array}$ \\
\hline & $\begin{array}{l}\text { Decomposition of } \\
\text { changes in } \\
\text { energy } \\
\text { consumption: } \\
\text { activity, structure } \\
\text { and intensity } \\
\text { effect }\end{array}$ & $\begin{array}{l}\text { Total service } \\
\text { energy } \\
\text { consumption. } \\
\text { - Total service value } \\
\text { added (in constant } \\
\text { currency). } \\
\text { - Service floor area. } \\
\text { - Total number of } \\
\text { employees. }\end{array}$ & $\begin{array}{l}\text { - Provide a general overview of the main factors } \\
\text { influencing the trends in services energy } \\
\text { consumption. } \\
\text { - Quantify the role of different drivers on the } \\
\text { aggregate energy intensity of the sector. } \\
\text { - The best indicator that can be built at present } \\
\text { with data available at IEA. }\end{array}$ & $\begin{array}{l}\text { Does not represent an estimation of the energy efficiency } \\
\text { for the service sector. } \\
\text { - Influenced by many non-efficiency factors such as the } \\
\text { changes in the structure of the building sector and } \\
\text { changes in end-use. }\end{array}$ \\
\hline
\end{tabular}




\section{Transport sector}

Transport energy consumption in Russia is available from the energy balance. However, it is not disaggregated by transport segment (passenger and freight). As a result, it is difficult to make any conclusions on the energy consumption trends in Russia's passenger transport sector. Any Moscovite can agree that since the early 1990s individual automotive vehicle ownership in Moscow has skyrocketed, as evidenced by the major daily traffic jams. Other major cities in Russia have experienced similar trends, but Moscow is by far the most striking.

In terms of the transport sector overall - including both passenger and freight and all modes of transport - as reported in Russia's energy balance, the transport sector saw its energy consumption drop to its lowest point in 1997 at less than 2800 PJ. In 1998, energy consumption in Russia's transport sector jumped over $16 \%$, a sign of the huge economic recovery which began in the second half of that year. Over the period from 1998 to 2008, energy consumption in Russia's transport sector increased $25 \%$.

\section{Passenger transport sector}

Passenger transport includes the movement of people by road, rail, water and air. Road transport is further sub-divided into light-duty vehicles (LDV) and buses. Only domestic air and water are included; international air and water travel are not covered.

Box 8. Energy efficiency trends in passenger transport sector

Global passenger transport energy consumption data are not available from a country's energy balances, as energy balances report only total transportation. As a result, analysis of the sector can be performed for only 19 IEA member countries. ${ }^{13}$ For those 19 countries, passenger transport energy consumption between 1990 and 2006 increased by $24 \%$, with the shares of the various modes remaining quite stable. Light-duty vehicles are, by far, the largest energy consumer, accounting for $87 \%$ of the energy consumption.

Passenger-kilometres $(\mathrm{pkm})$ and the efficiency of passenger transport modes (energy consumption per $\mathrm{pkm}$ ) are the two main determinants of energy consumption. Both are affected by a wide range of interacting factors such as: occupancy rate of vehicles; distance travelled; density of population; vehicle ownership; income levels of drivers; local transport policies; and price of fuel. Indicators that can be built with available data from the IEA energy efficiency indicators template show that only one factor helped to restrain growth in road transport energy demand: energy efficiency. Energy efficiency for LDVs improved by $6 \%$ since 1990.

\section{Availability of passenger transport data in Russia to develop indicators}

In many countries, passenger transport represents a significant and growing share of total energy consumption. In order to develop useful energy efficiency indicators in this sector, a large number of data are required. In the IEA energy efficiency indicators template, the minimal set of data required to develop indicators include:

- Energy consumption by transportation mode;

- Information on the passenger transportation fleet by mode (stock of vehicles);

\footnotetext{
${ }^{13}$ IEA 19 includes Australia, Austria, Canada, Denmark, Finland, France, Germany, Greece, Ireland, Italy, Japan, the Netherlands, New Zealand, Norway, Spain, Sweden, Switzerland, the United Kingdom and the United States.
} 
- Passenger kilometres by mode; and

- Vehicle kilometres by mode.

Transport energy consumption in Russia is only available from the energy balance; these data are disaggregated by mode (road, rail, water and air) but not by transport segment (passenger and freight). As a result, it is currently not possible to develop indicators for this sector.

Most activity data are available from Rosstat and disseminated in the publications Main Indicators of Transport Performances in Russia (Rosstat, 2010a) and Transport in Russia (Rosstat, 2010b). For passenger transport, available information includes passenger-kilometres, vehicle kilometres and vehicle stock for buses, trains and airplanes. Information for LDV is not available. As LDV generally represents the most important transportation mode, priority should focus on collecting activity data for this transportation mode.

Activity variables are equally important for developing indicators. As is the case for energy consumption, activity data can be collected or estimated through different means. Different countries are adopting different strategies to collect or develop passenger transport energy consumption and activity data: survey targeting households for LDVs; collecting information through fleet managers or operators for buses and trains; and developing modelling analysis to estimate energy consumption. The strategy adopted depends on several factors such as the availability of data driving energy consumption, the existence of surveys that can be amended to include more questions, etc.

The IEA identified potential sources of data that can constitute a starting point for estimating energy consumption by mode in the passenger transport sector, such as data available from administrative sources e.g. vehicle registration, information collected during the mandatory car annual verification, and data available from research institutes. Given the nature of administrative data, the collection of information from this source may require (as is the case in some IEA member countries) an official agreement between all the parties involved to support an adequate use of the information and ensure that the confidentiality of information is maintained.

Data that member countries are required to report to the IEA through the energy efficiency indicator template, the number of countries that are currently able to provide the data as well as the data currently available from Rosstat are presented in Table 7. The information collected is used to develop basic indicators to explain the changes in energy consumption over a period of time. Countries would benefit by complementing the data requested in the template with more detailed information on, for example, the vehicle stock turnover, size/class of vehicle and travel patterns.

\section{Key indicators for the passenger transport sector}

Numerous indicators, providing useful information to better understand the trends in energy consumption and energy efficiency, can be developed with the minimal set of data available from the IEA energy efficiency indicators template. The key indicators are presented in Table 8 along with an explanation of their purpose and limitations. 
Table 7: Passenger transport data needed to develop basic energy and energy efficiency indicators

\begin{tabular}{|c|c|c|}
\hline Data needed to develop indicators & $\begin{array}{l}\text { Number of IEA member } \\
\text { countries reporting the data }\end{array}$ & Data available from Russia \\
\hline \multicolumn{3}{|l|}{ Energy consumption by: } \\
\hline Energy source & 25 & Yes \\
\hline Transportation mode & 21 & No \\
\hline $\begin{array}{l}\text { Cars, Sport utility vehicles (SUVs) } \\
\text { and personal light trucks }\end{array}$ & 22 & No \\
\hline Motorcycles and three-wheelers & 10 & No \\
\hline Buses & 22 & No \\
\hline Passenger train & 24 & No \\
\hline Domestic passenger airplane & 23 & No \\
\hline Domestic passenger ships & 5 & No \\
\hline Passenger-kilometres by: & 20 & No \\
\hline Cars, SUVs and personal light trucks & 26 & No \\
\hline Motorcycles and three-wheelers & 6 & No \\
\hline Buses & 23 & Yes \\
\hline Passenger train & 25 & Yes \\
\hline Domestic passenger airplane & 20 & Yes \\
\hline Domestic passenger ships & 4 & Yes \\
\hline Vehicle kilometres by: & & No \\
\hline Cars, SUVs and personal light trucks & 23 & No \\
\hline Motorcycles and three-wheelers & 11 & No \\
\hline Buses & 19 & No \\
\hline Passenger train & 2 & No \\
\hline Domestic passenger airplane & 3 & No \\
\hline Domestic passenger ships & 1 & No \\
\hline \multicolumn{3}{|l|}{ Vehicle stocks by: } \\
\hline Cars, SUVs and personal light trucks & 26 & No \\
\hline Motorcycles and three-wheelers & 24 & Yes \\
\hline Buses & 25 & Yes \\
\hline Passenger train & 0 & Yes \\
\hline Domestic passenger airplane & 0 & No \\
\hline Domestic passenger ships & 1 & No \\
\hline
\end{tabular}

Note: IEA countries coverage indicates the number of IEA member countries for which data are currently available from 1990 to 2006 in the energy indicators database. Coverage for Russia is based on IEA knowledge of the data situation in Russia; which has been validated by the Russian Federation. 
Table 8: Key indicators to understand trends in energy and energy efficiency in passenger transport

\begin{tabular}{|c|c|c|c|c|}
\hline & Indicator & Data required & Purpose & Limitation \\
\hline \multirow{2}{*}{ 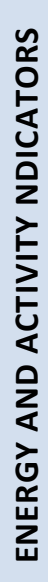 } & $\begin{array}{l}\text { Share of passenger- } \\
\text { kilometres by mode }\end{array}$ & $\begin{array}{l}\text { - Passenger-kilometres by } \\
\text { mode. }\end{array}$ & $\begin{array}{l}\text { Provide assessment of the change in the } \\
\text { share of modes. } \\
\text { Provide useful qualitative information on } \\
\text { activity trends in the sector. } \\
\text { - Provide qualitative information on how } \\
\text { change in activity influences change in } \\
\text { energy consumption. }\end{array}$ & $\begin{array}{l}\text { Only activity driven, does not provide a measure } \\
\text { of energy efficiency. } \\
\text { Travel patterns are influenced by many diverse } \\
\text { factors such as income, age profile of drivers, } \\
\text { gender of drivers, household size, flexible working } \\
\text { and leisure activities, geographic characteristics } \\
\text { and local transport policies. }\end{array}$ \\
\hline & $\begin{array}{l}\text { Energy use per } \\
\text { passenger-kilometre } \\
\text { by transportation } \\
\text { mode }\end{array}$ & $\begin{array}{l}\text { Passenger transport } \\
\text { energy consumption by } \\
\text { transport mode. } \\
\text { - Passenger-kilometres by } \\
\text { transport mode. }\end{array}$ & $\begin{array}{l}\text { Energy intensities by mode is a } \\
\text { meaningful summary indicator. } \\
\text { Intensities can be used to help develop } \\
\text { transportation energy policies. }\end{array}$ & $\begin{array}{l}\text { Still affected by factors that are not related to } \\
\text { energy efficiency such as vehicle weight for LDV, } \\
\text { vehicle occupancy and vehicle features. } \\
\text { If developed at the aggregate level (total LDV) } \\
\text { may mask important structural changes (number } \\
\text { of cars compared to SUVs). }\end{array}$ \\
\hline \multirow{3}{*}{ 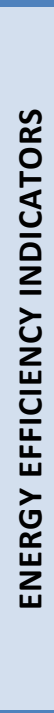 } & LDV fuel intensity & $\begin{array}{l}\text { - Stock of LDV. } \\
\text { - LDD vehicle kilometres. } \\
\text { - LDV energy consumption. }\end{array}$ & $\begin{array}{l}\text { Provide insights on the actual fuel } \\
\text { economy of the vehicle stock. } \\
\text { As opposed to LVD energy use per } \\
\text { passenger-kilometre, it is not influence } \\
\text { by vehicle occupancy. }\end{array}$ & $\begin{array}{l}\text { - If developed at the aggregate level (total LDV) } \\
\text { may mask important structural changes (shift } \\
\text { from cars to SUVs in some countries. }\end{array}$ \\
\hline & $\begin{array}{l}\text { Decomposition of } \\
\text { changes in total } \\
\text { passenger energy use: } \\
\text { activity, structure and } \\
\text { intensity effects }\end{array}$ & $\begin{array}{l}\text { - Passenger transport } \\
\text { energy consumption by } \\
\text { mode. } \\
\text { - Passenger-kilometres by } \\
\text { mode. }\end{array}$ & $\begin{array}{l}\text { - Quantify the factors influencing changes } \\
\text { in energy consumption. }\end{array}$ & $\begin{array}{l}\text { Does not reveal how different factors, such as an } \\
\text { increase in car ownership, are affecting each } \\
\text { transport mode. }\end{array}$ \\
\hline & $\begin{array}{l}\text { Decomposition of } \\
\text { changes in LDV energy } \\
\text { use: ownership effect, } \\
\text { usage effect and fuel } \\
\text { intensity effect. }\end{array}$ & $\begin{array}{l}\text { - LDV energy consumption. } \\
\text { - Stock of LDV. } \\
\text { - Population. } \\
\text { - Distance travelled. }\end{array}$ & $\begin{array}{l}\text { Quantify the effect of LDV fuel intensity } \\
\text { (a proxy for energy efficiency) on LDV } \\
\text { energy consumption. } \\
\text { The best indicator that can be developed } \\
\text { for LDV with the data required in the IEA } \\
\text { energy efficiency indicators template. }\end{array}$ & $\begin{array}{l}\text { Includes effects that are not related to lab-tested } \\
\text { fuel economy such as size of vehicles and } \\
\text { geographic conditions. }\end{array}$ \\
\hline
\end{tabular}




\section{Freight transport sector}

Freight transport includes the domestic movement of goods by road, rail, air and ships water. Transport through pipelines is excluded.

As is the case with passenger transport, freight transport ${ }^{14}$ energy consumption data are not available from country energy balances and the analysis can be performed only for 19 IEA member countries. ${ }^{15}$

For these 19 countries, freight transport energy consumption increased by $31 \%$ between 1990 and 2006. Trucks are by far the largest energy user, accounting for $83 \%$ of the overall freight transport energy consumption in 2006.

The energy intensities of trucks, trains and ships vary significantly. For the 19 countries for which the information is available, trains are the most energy efficient mode of freight transport. On average, for the 19 countries, it requires 10 times less energy to transport one tonne of goods over one kilometre by train than by truck. The difference in intensity between modes has important implications for energy consumption trends: because of its much higher energy intensity, growth in truck freight haulage drives up energy consumption much more quickly than growth in trains or ships. Consequently, efforts to reduce the intensity of trucking will lead to higher energy savings than reductions in trains and ships. Important energy savings can also be achieved by increasing the share of rail, ships and air in freight transport.

\section{Availability of freight transport data in Russia to develop indicators}

In order to develop useful energy and energy efficiency indicators in this sector, a large number of data are required. In the IEA energy efficiency indicators template, the minimal set of data required to develop indicators include:

- Energy consumption by transportation mode;

- Information on the freight transportation fleet by mode (stock of vehicles);

- Tonne-kilometres by mode; and

- Load factors by mode.

Transport energy consumption in Russia is available only from the energy balance; these data are disaggregated by mode (road, rail, water and air) but not by transport segment (passenger and freight). As a result, it is currently not possible to develop indicators for the freight transport sector. It is essential to collect or develop the energy consumption information to develop indicators. As is the case in the passenger transport segment, different countries are adopting different strategies to collect or develop this information such as usage of truck fuel meter; collecting information through fleet managers or operators; and developing modelling analysis to estimate energy consumption. The strategy adopted depends on several factors.

Activity variables are equally important for developing indicators. While tonne-kilometres provide the basis for developing freight transport indicators, it is important to complement this information with load factors (as there is a strong correlation between changes in load factors and changes in the intensity of truck freight haulage) and stock of vehicles. As is the case for energy consumption, activity data can be collected or estimated through different means.

\footnotetext{
${ }^{14}$ While air freight transport data are requested in the IEA indicators database, the analysis excludes this mode because of lack of data separating domestic and international journey.

${ }^{15}$ IEA 19 includes Australia, Austria, Canada, Denmark, Finland, France, Germany, Greece, Ireland, Italy, Japan, the Netherlands, New Zealand, Norway, Spain, Sweden, Switzerland, the United Kingdom and the United States.
} 
Table 9: Freight transport data needed to develop basic energy and energy efficiency indicators

\begin{tabular}{|c|c|c|}
\hline Data needed to develop indicators & $\begin{array}{l}\text { Number of IEA member } \\
\text { countries reporting the data }\end{array}$ & $\begin{array}{c}\text { Data available from } \\
\text { Russia }\end{array}$ \\
\hline \multicolumn{3}{|l|}{ Energy consumption by: } \\
\hline Energy source & 24 & No \\
\hline Transportation mode & 21 & No \\
\hline $\begin{array}{l}\text { Freight and commercial road } \\
\text { transport }\end{array}$ & 22 & No \\
\hline Freight trains & 4 & No \\
\hline Domestic freight airplanes & 5 & No \\
\hline Domestic freight ships & 22 & No \\
\hline Freight tonne-kilometres ${ }^{16}$ by: & 24 & Yes \\
\hline Freight and commercial road transport & 19 & Yes \\
\hline Freight trains & 0 & Yes \\
\hline Domestic freight airplanes & 0 & Yes \\
\hline Domestic freight ships & 0 & Yes \\
\hline Freight tonnes transport ${ }^{17}$ by: & & Yes \\
\hline Freight and commercial road transport & 6 & Yes \\
\hline Freight trains & 5 & Yes \\
\hline Domestic freight airplanes & 4 & Yes \\
\hline Domestic freight ships & 3 & Yes \\
\hline \multicolumn{3}{|l|}{ Vehicle kilometres by: } \\
\hline Freight and commercial road transport & 20 & No \\
\hline Freight trains & 3 & No \\
\hline Domestic freight airplanes & 0 & No \\
\hline Domestic freight ships & 0 & No \\
\hline \multicolumn{3}{|l|}{ Vehicle stocks ${ }^{18}$ by: } \\
\hline Freight and commercial road transport & 25 & Yes \\
\hline Freight trains & 0 & Yes \\
\hline Domestic freight airplanes & 0 & No \\
\hline Domestic freight ships & 0 & No \\
\hline
\end{tabular}

Note: IEA countries coverage indicates the number of IEA member countries for which data are currently available from 1990 to 2006 in the energy indicators database. Coverage for Russia is based on IEA knowledge of the data situation in Russia; which has been validated by the Russian Federation.

Activity data are available from Rosstat and disseminated in the publications Main Indicators of Transport Performances in Russia (Rosstat, 2010a) and Transport in Russia (Rosstat, 2010b). The

\footnotetext{
${ }^{16}$ Covers only large companies; small trucking firms and individual owners are not included.

${ }^{17}$ Covers only large companies; small trucking firms and individual owners are not included.

${ }^{18}$ Covers only large companies; small trucking firms and individual owners are not included.
} 
available information includes tonne-kilometres, load factors and vehicle-kilometres. The activity data are available for trucks, trains and planes. No information is available for ships. However, the information collected by Rosstat is currently available only for large companies; small trucking firms and individual owners are not included. But additional questions that will be added to the National Household Budget Survey may help in gathering information on individual vehicles used for freight transportation.

Other potential existing sources of data (such as administrative data, or data from research institutes) can constitute a starting point for estimating freight transport energy consumption by mode.

Data that member countries are required to report to the IEA through the energy efficiency indicator template, the number of countries that are currently able to provide the data as well as the data currently available from Rosstat are presented in Table 9. The information collected is used to develop basic energy indicators to explain the changes in energy consumption over a period of time. This is a starting point for developing indicators. Countries would benefit by complementing the data requested in the template with more detailed information on, for example, the vehicle stock turnover, the size/class of trucks, or the empty versus loaded kilometres travelled.

\section{Key indicators for the freight transport sector}

The information required in the indicators database allows the development of the key energy and energy efficiency indicators presented in Table 10. 
Table 10: Key indicators to understand trends in energy and energy efficiency in freight transport

\begin{tabular}{|c|c|c|c|c|}
\hline & Indicator & Data required & Purpose & Limitation \\
\hline \multirow{3}{*}{ 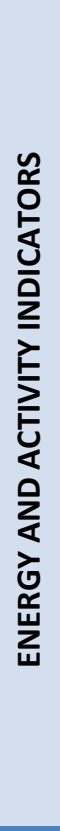 } & $\begin{array}{l}\text { Share of tonne- } \\
\text { kilometres by } \\
\text { mode }\end{array}$ & $\begin{array}{l}\text { Freight transport tonne- } \\
\text { kilometres by mode. }\end{array}$ & $\begin{array}{l}\text { Provide assessment of the change in the } \\
\text { share of modes. } \\
\text { Provide useful qualitative information on } \\
\text { activity trends in the sector. } \\
\text { Provide qualitative information on how } \\
\text { change in activity influence change in energy } \\
\text { consumption. }\end{array}$ & $\begin{array}{l}\text { Only activity driven, does not provide a measure of } \\
\text { energy efficiency. } \\
\text { Tonne-kilometres are influenced by many factors such } \\
\text { as availability of infrastructure, capacity utilisation, } \\
\text { type of goods moved, and the size and geography of } \\
\text { the country. }\end{array}$ \\
\hline & $\begin{array}{l}\text { Energy use per } \\
\text { tonne- } \\
\text { kilometre by } \\
\text { transportation } \\
\text { mode }\end{array}$ & $\begin{array}{l}\text { Freight transport energy } \\
\text { consumption by mode. } \\
\text { Freight transport tonne- } \\
\text { kilometres by mode. }\end{array}$ & $\begin{array}{l}\text { Energy intensities by mode are meaningful } \\
\text { summary indicators. } \\
\text { - Intensities can be used to help develop } \\
\text { transportation energy policies. }\end{array}$ & $\begin{array}{l}\text { Still affected by factors that are not related to energy } \\
\text { efficiency such as vehicle weight for trucks and load } \\
\text { factors. } \\
\text { May mask important structural changes in the road } \\
\text { segment. }\end{array}$ \\
\hline & $\begin{array}{l}\text { Truck average } \\
\text { load per vehicle }\end{array}$ & $\begin{array}{l}\text { Truck average load per } \\
\text { vehicle. }\end{array}$ & $\begin{array}{l}\text { Help explain the changes in truck energy } \\
\text { consumption per tonne-kilometres. } \\
\text { ftrong correlation between changes in load } \\
\text { factors and changes in the energy intensity of } \\
\text { truck freight haulage. }\end{array}$ & $\begin{array}{l}\text { This indicator, taken by itself, does not provide } \\
\text { indication on the trend in energy efficiency for trucks. } \\
\text { The average load can result from the change in the } \\
\text { composition of the fleet. }\end{array}$ \\
\hline 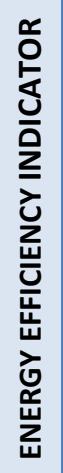 & $\begin{array}{l}\text { Decomposition } \\
\text { of changes in } \\
\text { energy use: } \\
\text { activity, } \\
\text { structure and } \\
\text { intensity } \\
\text { effects. }\end{array}$ & $\begin{array}{l}\text { Freight transport energy } \\
\text { consumption by mode. } \\
\text { Freight transport tonne- } \\
\text { kilometres by mode. }\end{array}$ & $\begin{array}{l}\text { Quantify the factors influencing change in } \\
\text { energy consumption. }\end{array}$ & $\begin{array}{l}\text { Does not provide how different factors, for example } \\
\text { change in the load factors, are affecting each } \\
\text { transport mode. } \\
\text { More detailed information is required to develop } \\
\text { strong indicators to better support development of } \\
\text { energy efficiency policies. }\end{array}$ \\
\hline
\end{tabular}




\section{Conclusions and next steps}

Developing, applying and deriving benefit from energy efficiency indicators implies a long-term commitment to collecting and analysing a broader range of energy data. Many IEA member governments have taken decades to establish effective and least-cost data collection systems based on strong co-ordination among the main statistical agency and other departments and agencies and the private sector.

The IEA is keen to continue its work with Russia in this area. Given the political momentum generated by the president's ambitious energy efficiency goals, the time is ripe for a push forward on developing such a co-ordinated system of data collection for energy efficiency indicators. Moreover, there is now an increasing and realistic understanding of the availability of data needed (and the gaps in data) to underpin the provision of energy efficiency indicators.

A key message the IEA has been promoting in discussions with Russian counterparts is the need to prioritise requirements for energy efficiency indicators. Specifically, the IEA recommends that this be done in consultation between energy experts (who are involved in the design, implementation and monitoring of energy efficiency policies) and statistical and analytical experts (who are responsible for the collection and analysis of data). Currently, data collectors are overwhelmed by the proposals for collection of many different data. Moreover, the creation of an overly large and complex system of energy efficiency indicators may prove to have a limited value added. At this early stage, Russia may derive greater value from a more simple set of indicators that concentrate on key aspects of energy efficiency in high energy intensity sectors such as industry, transport and residential.

While the clear commitment at the highest political level in Russia for substantial energy efficiency is widely recognised, there is not yet consensus on the key indicators needed by those developing energy efficiency policy and monitoring its implementation. Given the cross-agency nature of energy efficiency indicators, it may be beneficial to form a cross-governmental working group to improve co-ordination. The working group should ideally include all the major players, including government departments and institutions, and, where appropriate, research institutions and trade bodies (particularly where these hold relevant data or analytical expertise).

There could be benefit in a concrete focus, for example, such as having the working group initially explore co-ordination needs in Russia's transport sector, which the IEA found to have the largest data gaps. Russia is not unique in this respect: the transport sector is one of the most difficult sector in which to collect reliable data. The IEA has singled out the approaches of New Zealand and the United Kingdom as best practice examples; both countries have published reports ${ }^{19}$ outlining their data collection system in this sector.

This cross-governmental working group should take into account wide international experience, including that of the IEA, the European Union and individual countries. A co-ordinating body could be identified to take the lead on this, such as the Russian Energy Agency.

The IEA stands ready to continue working with Russia in this important area to ensure the effective implementation of its Law on Energy Efficiency and the achievement of its ambitious energy efficiency goals.

\footnotetext{
${ }^{19}$ Transport Statistics Great Britain, Department of Transport, 2009 Edition; and New Zealand Transport Statistics, Ministry of Transport, July 2009
} 


\section{Annex A. The IEA indicator approach}

Governments around the world are facing the complex and interlinked challenges of reducing energy consumption and associated GHG emissions while also meeting economic development goals. There is a growing recognition that improving energy efficiency is often the most economic, proven and readily available means to do this.

Tracking trends in energy efficiency is not an easy task. While overall energy consumption may be increasing due to robust GDP growth and/or an expanding population, energy efficiency may well be improving. Energy efficiency is only one of a number of factors that impact energy use. As such, it is possible to have improving energy efficiency while still seeing increases in energy consumption. Some factors that may cause (explain) growth in energy consumption include: population growth; a colder or warmer than usual winter; a change in structure of the industrial sector; an increase in wealth (as measured by GDP per capita); an increase in the level of ownership of appliances and/or equipment; and a change in consumer behaviour or preferences. Disentangling these various factors that drive and restrain energy use is the key purpose of energy indicators. In this respect, energy indicators provide policy makers with the tools to make informed policy decisions to target the key end-use area or consumer behaviour that is driving energy consumption.

\section{The benefits of the IEA approach}

The IEA indicator approach uses a pyramid that portrays a hierarchy of energy indicators from most detailed (at the bottom of the pyramid) to least detailed (at the top of the pyramid). This illustrates conceptually how the most detailed and disaggregated data and indicators can be combined to reveal the more aggregated ones higher up on the pyramid. This hierarchy is important because it shows how detailed changes (which may be the result of policies, technological progress, structural reform or behavioural change) can be linked to higher order, more aggregate quantities, showing how the former affects the latter. With this hierarchy, one can better explain more aggregate changes in energy use in terms of components and more carefully choose the depth of analysis required. This hierarchy will be different from country to country as it depends on the data availability and the questions that need to be answered.

\section{Examples:}

- The five most energy intensive industrial sectors are pulp and paper, chemicals and petrochemicals, iron and steel, cement and aluminium. Because of their much higher energy intensity, growth in these industrial sectors will drive up energy consumption much more quickly than growth in less intensive sectors. For example an increase in cement, using about 20 Megajoules (MJ) per unit of GDP, will have a much bigger impact on energy consumption than an increase in the fabrication of metal products, using less than $5 \mathrm{MJ}$ per unit of GDP.

- In the iron and steel sector, a relative decrease in the use of open hearth furnace (a very intensive process) will have a downward effect on energy consumption. So a decrease in the iron and steel intensity (in terms of energy use per unit of production) will not necessarily indicate an improvement in energy efficiency in a particular production process: it can be caused by a switch of production from open-hearth furnaces to blast furnaces. 


\section{The IEA indicator pyramid}

The top row of the pyramid (the most aggregate indicator) is defined as the ratio of energy use to gross domestic product (GDP). Alternatively, it could be defined as the ratio of energy use to another macro-economic variable, such as population.

The second row of elements can be defined as the energy intensity of each major sector, as measured by energy use per unit of activity in each sector.

Lower rows represent the sub-sectors or end-uses that make up each sector and progressively provide more detail e.g. characterising particular processes or appliances.

Joining each level of energy intensities are structural variables that indicate how to weight these intensities to form a more aggregate parameter of intensity or use. Descending lower down the pyramid requires more data and more complex analysis to re-aggregate back up to a higher level. However, each descent also provides a better measure of "technical" energy efficiency defined for a specific technology, process and/or end-use, but also required more data.

Figure A.1: The IEA indicator pyramid

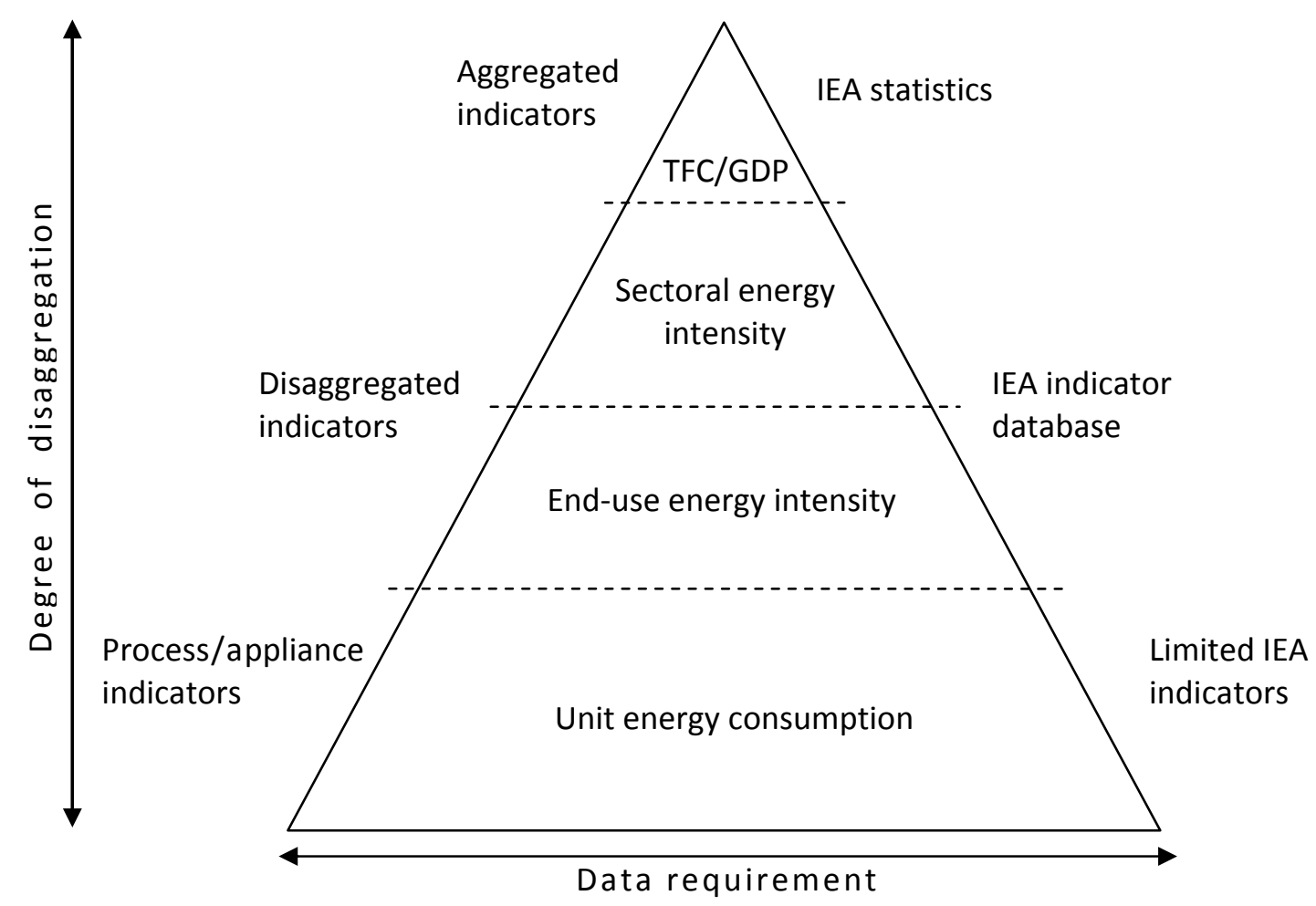

Note: Indicators shown are just on example among those available. 


\section{Example of indicator pyramid: Industry sector}

The industry sector covers the manufacture of finished goods and products, mining and quarrying of raw materials, and construction. Power generation, refineries and the distribution of electricity, gas and water are excluded.

The industrial pyramid shows how this sector can be disaggregated and the different indicators that can be used at each level (Figure A.2). This is only an illustration and may not be relevant for all countries.

Figure A.2: Industry sector pyramid

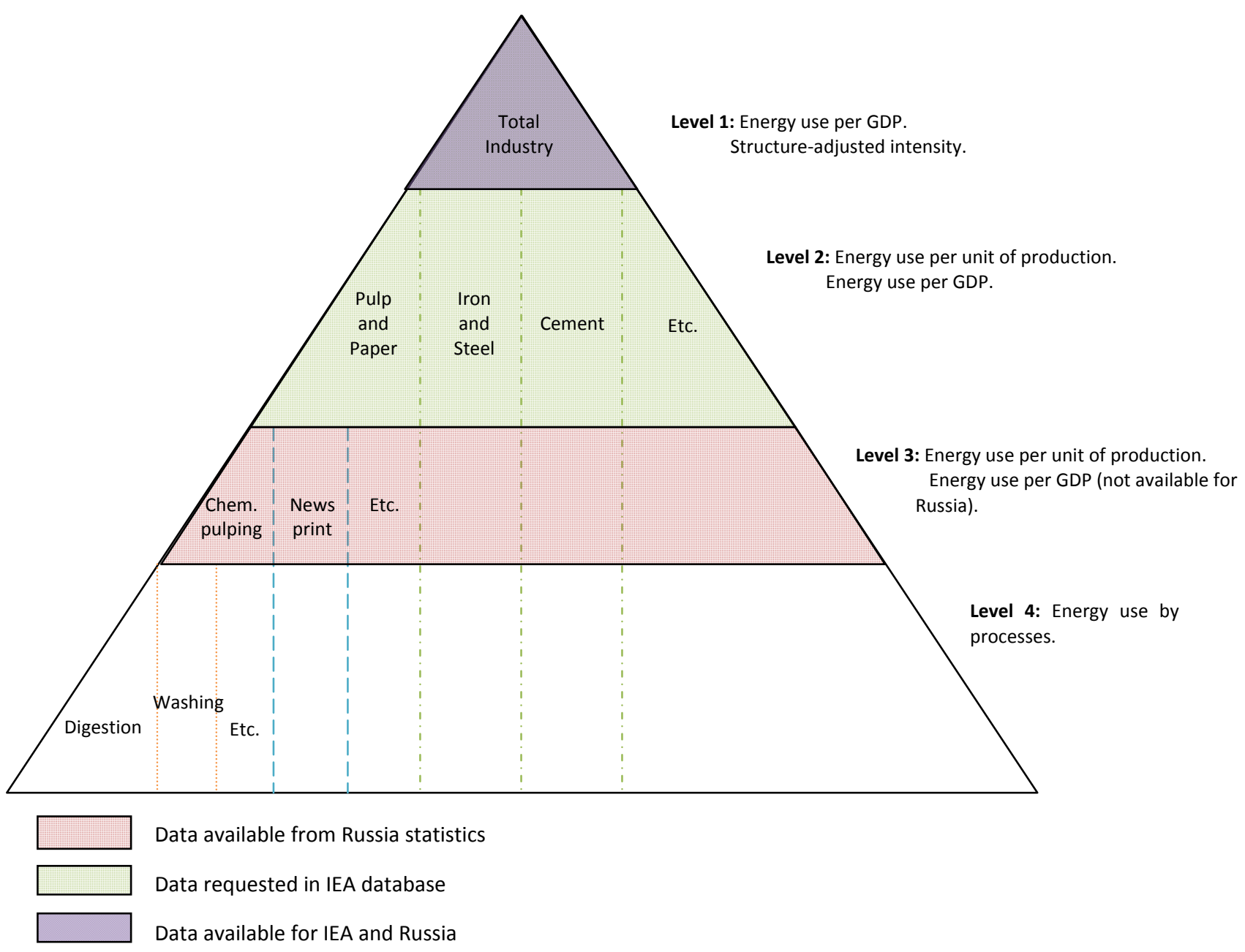

Note: Russia has very detailed energy and production statistics for industry. However, it is not possible to aggregate them to higher levels in the pyramid due to lack of associated GDP data in constant currency. For IEA countries, the IEA database contains information at Level 2 for 21 member countries in the industrial sector. Some countries have more detailed information than what is available in the IEA database. 


\section{Level 1: Total industry sector}

The commonly used indicator at the aggregate level is energy use per unit of GDP. This ratio measures how much energy is needed to produce one unit of economic output. However, it would be misleading to evaluate the performance of energy efficiency based on this indicator as it is affected by many non-energy efficiency factors such as the structure of the industry, the quality of resources and, for some industrial sectors, weather conditions.

For this reason, many countries develop structure-adjusted intensity for the total industrial sector. Constructing the structure-adjusted indicator requires the energy use and GDP data at Level 2 or 3 of the pyramid.

\section{Level 2 and level 3: Industry sectors}

The industries represented in Level 2 and 3 usually differ by country according to the data available and the relative importance of each industry.

At these levels, the best indicator to assess energy efficiency is energy use per unit of production. However, as some industries are too heterogeneous to have one measure of production, GDP (or another monetary value such as gross output) is the second-best choice.

\section{Level 4: Process indicators}

The IEA indicator database does not contain information on Level 4. Only a limited number of countries have this information for a limited number of industries. However, even partial information at this level can help explain the trends in energy consumption.

\section{Example of indicator pyramid: Residential sector}

The residential sector includes those activities related to private dwellings. It covers all energyusing activities in apartments and houses, including space and water heating, cooling, lighting and the use of appliances. It does not include personal transport, which is covered in the transport sector.

There are numerous ways to define the analytical framework in the residential sector. The level of detail selected greatly depends on the information available. For example, Canada is using two different pyramids: one for end-uses with energy consumption related to the number of households and one for end-uses with energy consumption related the floor area. The indicators are then aggregated by using weighted energy consumption.

The example below shows the two indicators pyramids for the residential sector. These pyramids would be applicable to countries with rather detailed end-use data. This is not the case in each country. As previously mentioned, the pyramid should be adapted to account for countries specificities and data situation. 
Figure A.3: Residential sector pyramid based on floor area

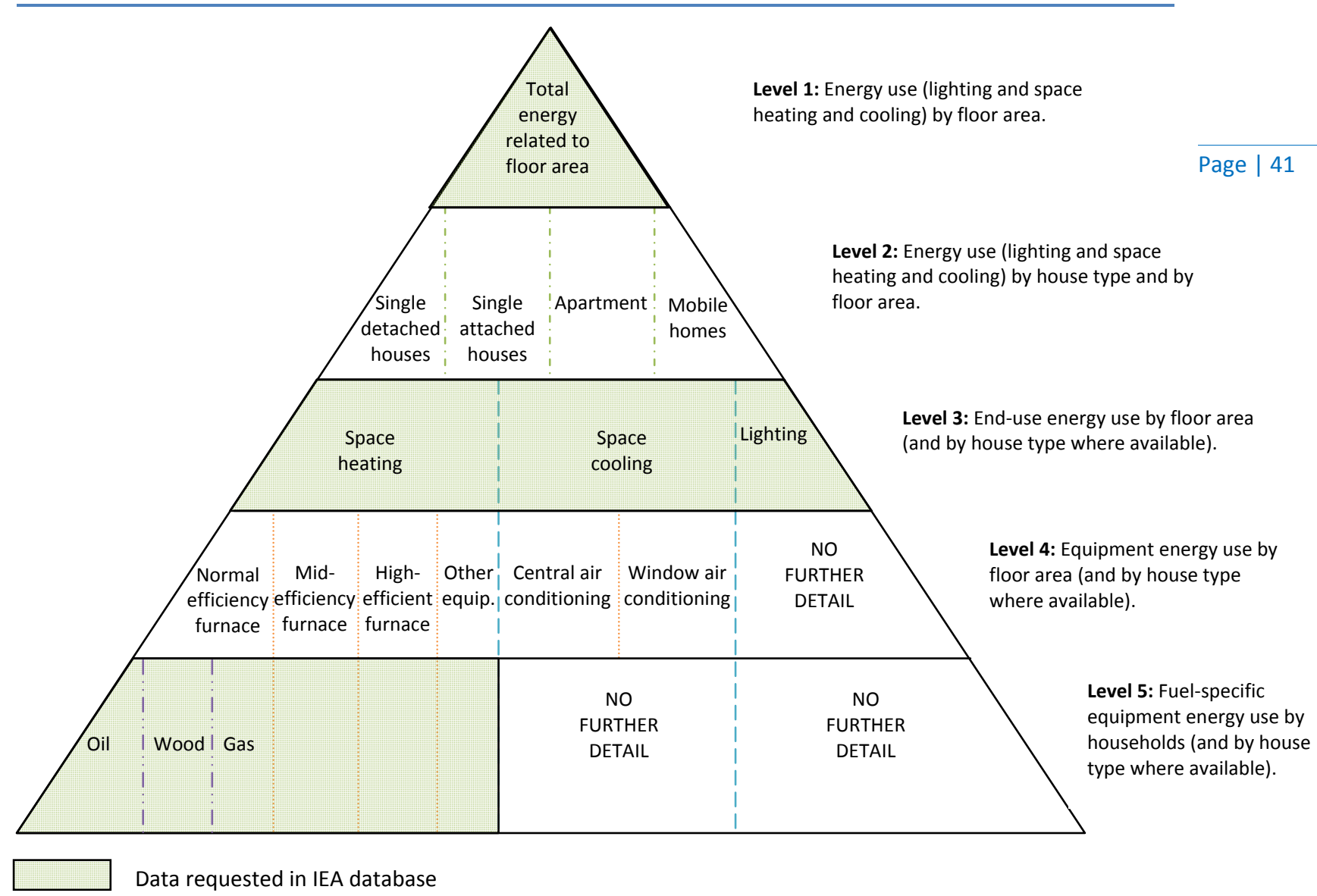

Note: For Russia, the information is not available by end-uses; but if the pyramid is to be defined without the breakdown by end-use, it would be possible to do the analysis at the Level 2 . Information by house type and by housing systems is available in some countries (such as Canada). However, this information is not collected by the IEA. The IEA database contains information for levels 1, 3 and 5 for 19 IEA member countries. Some countries have more detailed information than what is available in the IEA database. 
Figure A.4: Residential sector pyramid based on household

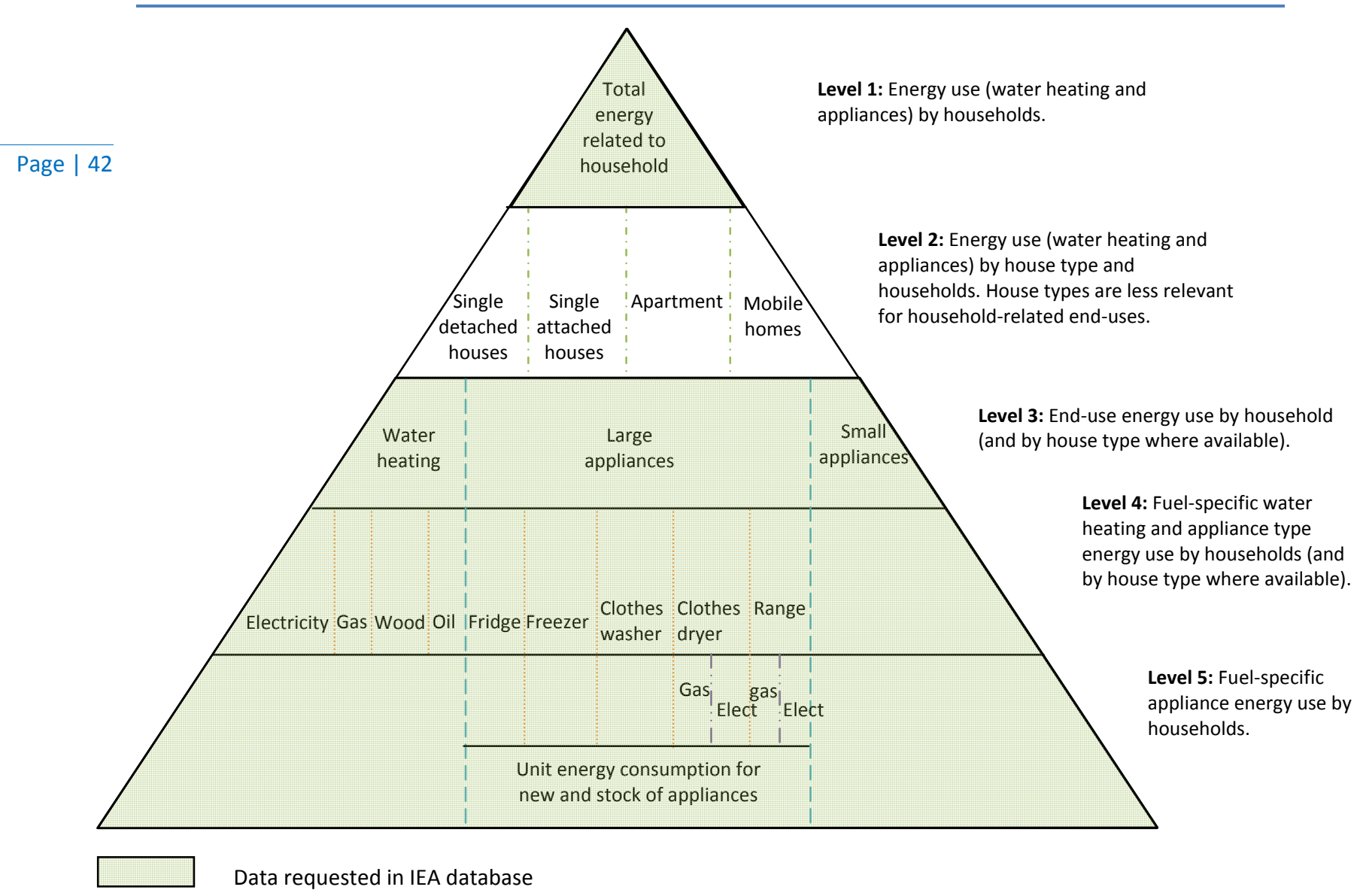

Note: For Russia, the information is not available by end-uses; but if the pyramid is to be defined without the breakdown by end-use, it would be possible to do the analysis at the Level 2 . Information by house type and by housing systems is available in some countries (such as Canada). However, this information is not collected by the IEA. The IEA database contains information for levels $1,3,4$ and 5 with the number of country reporting the data to IEA depending on the level of the pyramid. Some countries have more detailed information than what is available in the IEA database. 


\section{Example of indicator pyramid: Service sector}

The service sector includes activities related to trade, finance, real estate, public administration, health, education and commercial services.

Very few countries are able to analyse the energy efficiency trends in the service sector. The general aggregate indicator used is service energy consumption by unit of value added in the service sector. However, different service sector activities can produce very different levels of economic output while consuming nearly the same amount of energy. For example, buildings in the finance sector can have the same final energy demand profile as buildings in the retail sector, yet generate significantly different levels of economic output.

Energy consumption by floor area is considered by some countries as the best indicator for this sector.

Figure A.5: Service sector pyramid

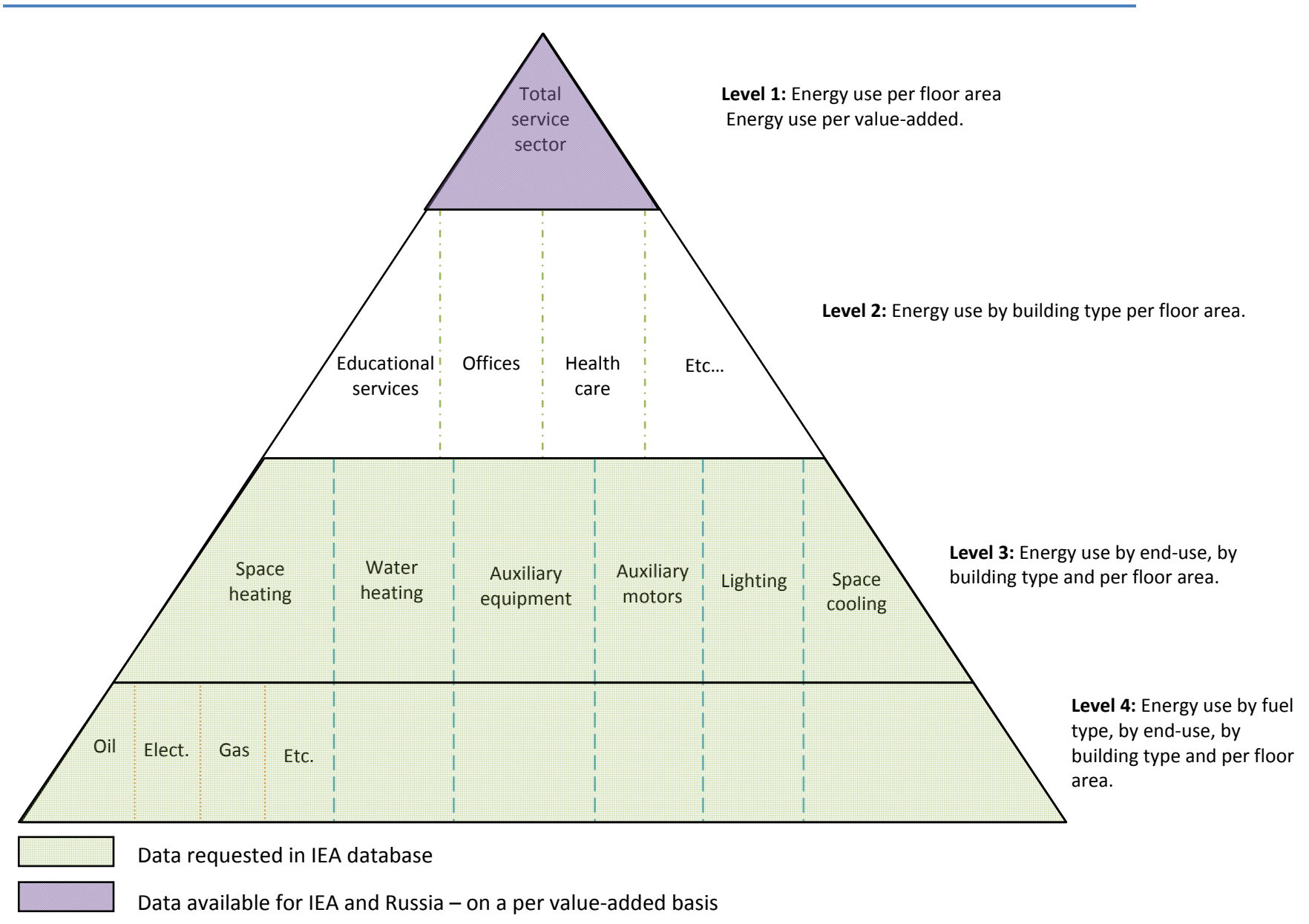

Notes: For Russia, total energy consumption and value-added data are available. For IEA member countries, only three countries report energy use by end-use to the IEA (Level 3). Only seven countries report total service floor area. The IEA is analysing the service sector intensity based on value added. Some countries have more detailed information than what is available in the IEA database. 


\section{Example of indicator pyramid: Transport sector}

The transport sector includes the movement of people and goods by road, rail, water and air. Pipelines and international air and water transport are excluded from the analysis.

While it is possible to present energy use for the total transport sector, a more detailed analysis of this sector requires passenger and freight transport to be analysed separately since they are affected by different underlying factors.

Figure A.6: Passenger transport sector pyramid

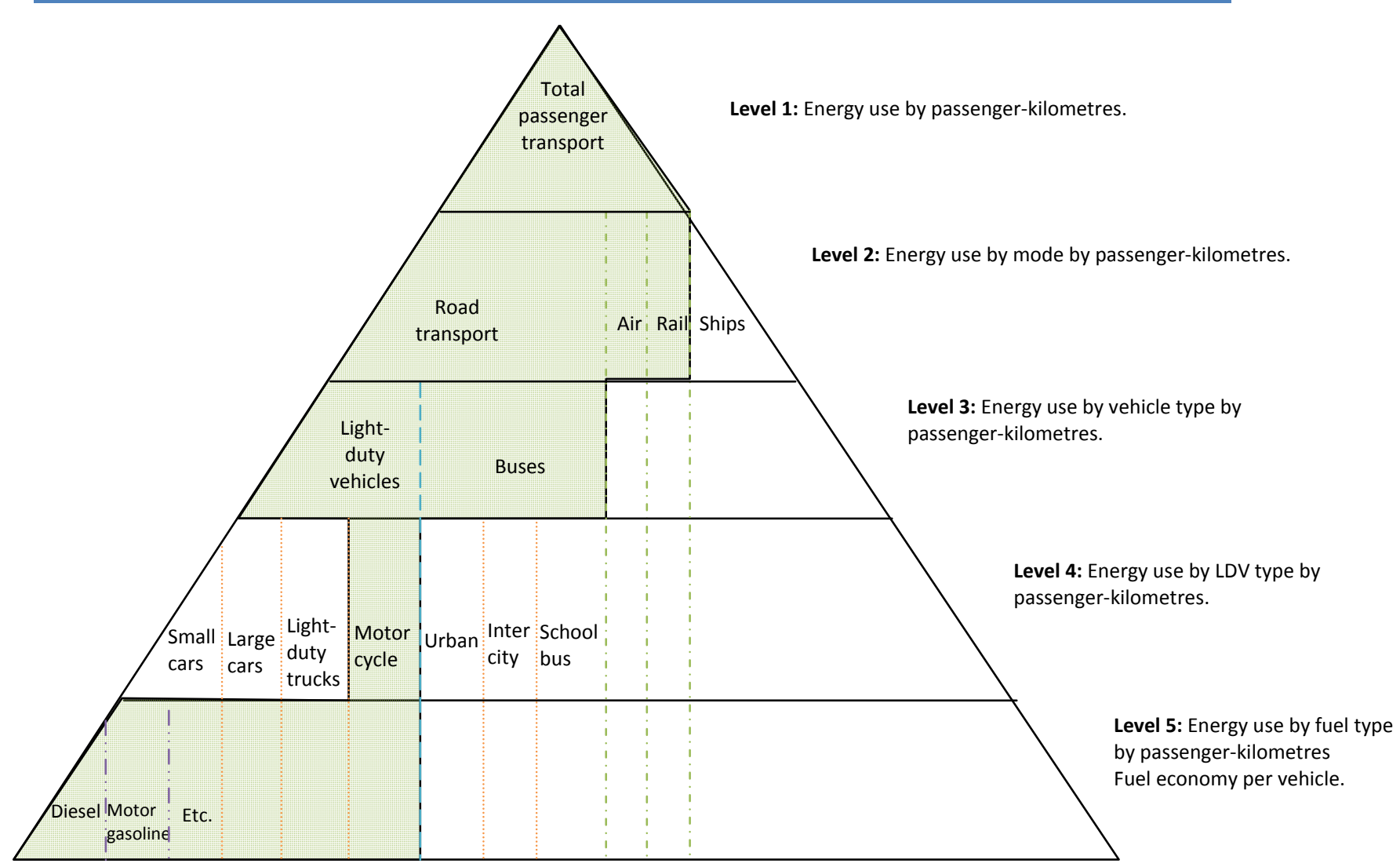

Data requested in IEA database

Notes: Only activity information for buses, air and rail is available for Russia. The IEA database does not contain information by type of buses. Ships are not included in the IEA analysis due to lack of information. In the IEA database, light-duty vehicles are only disaggregated only between motorcycles and other LDVs. Some countries have more detailed information than what is available in the IEA database. 
Figure A.7: Freight transport sector pyramid

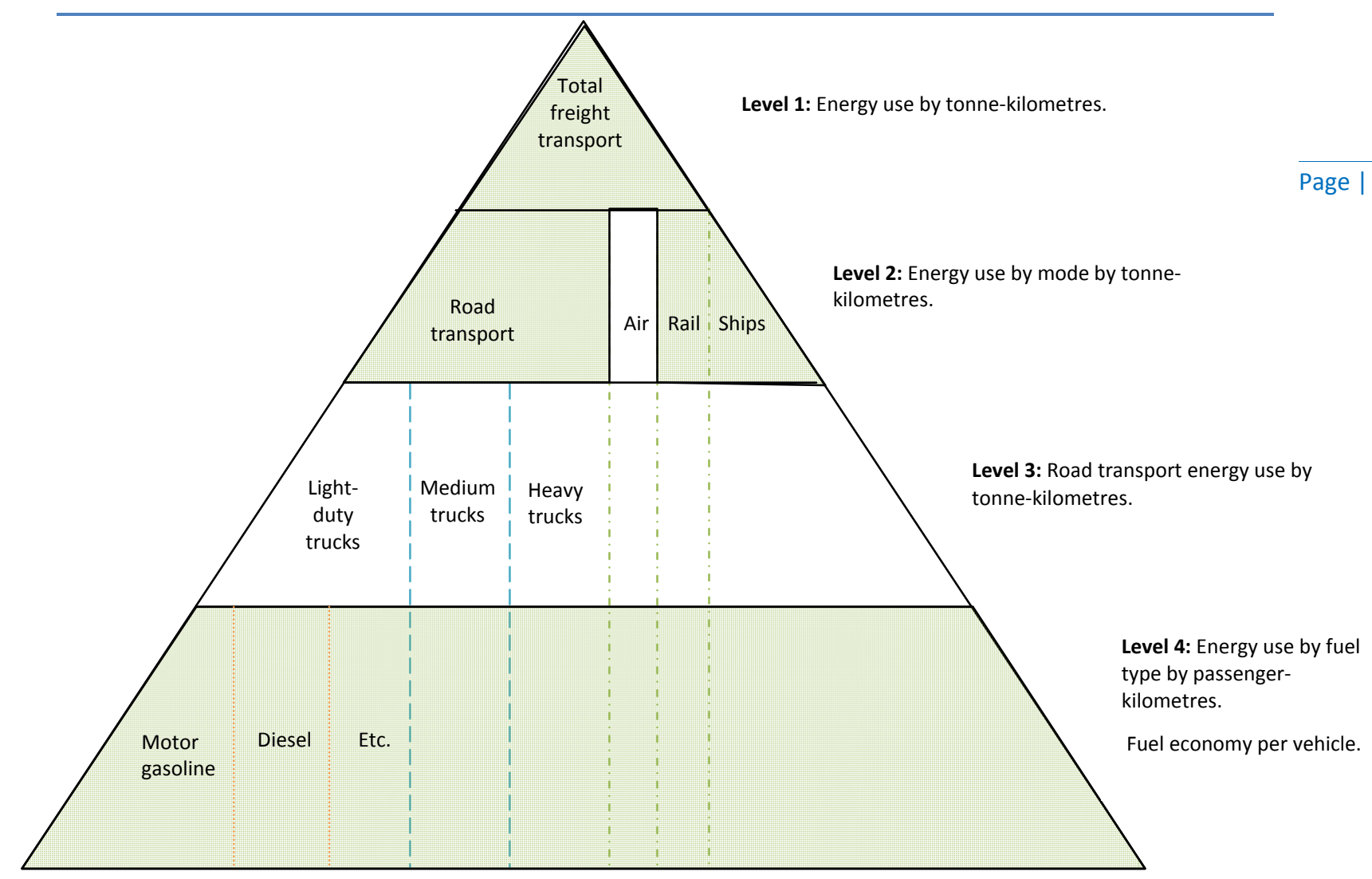

Data requested in IEA database

Notes: Only activity information is available for Russia. The IEA database does not contain information by type of road freight vehicles. Air travel is not included in the IEA analysis due to lack of information. Some countries have more detailed information than what is available in the IEA database. 


\section{Annex B. The IEA methodology for analysing energy consumption}

\section{Page | 46 The decomposition of changes in energy consumption}

The analysis of energy end-use trends distinguishes between three main components affecting energy consumption: aggregate activity, sectoral structure and energy intensities (see Table B.1 for more details).

Aggregate activity (A) is measured in one of the following ways, depending on the sector: as value added for manufacturing industry and services; as population in the residential sector; or as passenger-kilometres and tonne-kilometres, respectively, for the passenger and freight transport sectors.

Sectoral structure (S) represents the mix of activities within a sector and further divides activity into industry sub-sectors, measures of residential end-use activity or transportation modes.

Energy intensity (I) refers to energy use per unit of activity.

To separate the effect of various components over time, the IEA uses a factoral decomposition approach that analyses changes in energy use within a sector, using the following equation:

$$
\boldsymbol{E}=\boldsymbol{A} \cdot \sum_{r}\left(\boldsymbol{S}^{r} \cdot \boldsymbol{I}^{r}\right)
$$

In this decomposition, the symbols represent the following parameters:

E Total energy use in a sector.

A Overall sectoral activity.

$r \quad$ Sub-sectors or end-uses within a given sector.

$S^{r} \quad$ Share of sub-sector or end-use " $r$ " in a sector.

$I^{r} \quad$ Energy intensity of each sub-sector or end-use " $r$ ".

The activity effect can be calculated as the relative impact on energy use that would have occurred in year $t$ if the structure and energy intensities for a sector had remained fixed at their base year values $(t=0)$ while aggregate activity had followed its actual development.

$$
E_{t}^{A}=\frac{A_{t} \cdot \sum_{r}\left(S_{0}^{r} \cdot I_{0}^{r}\right)}{E_{0}}
$$

Similarly, the structure effect is determined by making the calculation using constant aggregate activity and energy intensities but varying the sectoral structure.

$$
E_{t}^{S}=\frac{A_{0} \cdot \sum_{r}\left(S_{t}^{r} \cdot I_{0}^{r}\right)}{E_{0}}
$$

The intensity effect is calculated by assuming that the sectoral structure and aggregate activity for a sector had remained fixed at the base year values while energy intensities had followed their actual development.

$$
E_{t}^{I}=\frac{A_{0} \cdot \sum_{r}\left(S_{0}^{r} \cdot I_{t}^{r}\right)}{E_{0}}
$$


Thus, by calculating the relative impact on energy use from changes in each of these components, it is possible to isolate the impacts on energy use related to improved end-use energy efficiency (reductions in energy intensities) - i.e. to separate these impacts from changes deriving from shifts in the activity and structure components.

In this analysis, the hypothetical energy use (HEU') is defined as the energy use that would have occurred in year $t$ if energy intensities in each sector remained constant at their base year values. It is calculated by dividing actual energy use in year $t$ by the intensity effect in that year.

$$
H E U_{t}^{I}=\frac{E_{t}}{E_{t}^{I}}
$$

Energy savings from reduced energy intensities can be defined as the difference between the hypothetical energy use and actual energy use.

$$
\text { SAVINGS } S_{t}^{I}=H E U_{t}^{I}-E_{t}
$$

\begin{tabular}{|c|c|c|c|c|}
\hline Sector & Sub-sector & Activity (A) & Structure (S) & Intensity (I) \\
\hline \multicolumn{5}{|c|}{ Residential } \\
\hline & Space heating & Population & Floor area / population & $\begin{array}{c}\text { Space heating } \\
\text { energy }^{1} \text { / floor area }\end{array}$ \\
\hline & Water heating & “ & $\begin{array}{c}\text { Population / occupied } \\
\text { dwellings }\end{array}$ & $\begin{array}{c}\text { Water heating } \\
\text { energy }{ }^{2} / \text { occupied } \\
\text { dwelling }\end{array}$ \\
\hline & Cooking & “ & $\begin{array}{l}\text { Population / occupied } \\
\text { dwellings }\end{array}$ & $\begin{array}{l}\text { Cooking energy / } \\
\text { occupied dwellings }\end{array}$ \\
\hline & Lighting & $“$ & Floor Area / population & $\begin{array}{l}\text { Lighting energy / } \\
\text { floor area }\end{array}$ \\
\hline & Appliances & " & $\begin{array}{l}\text { Appliances ownership / } \\
\text { population }\end{array}$ & $\begin{array}{l}\text { Appliances energy / } \\
\text { appliance ownership }\end{array}$ \\
\hline \multicolumn{5}{|c|}{ Passenger Transport } \\
\hline & Car & $\begin{array}{l}\text { Passenger- } \\
\text { kilometre }\end{array}$ & $\begin{array}{l}\text { Share of passenger- } \\
\text { kilometre }\end{array}$ & $\begin{array}{l}\text { Energy / passenger- } \\
\text { kilometre }\end{array}$ \\
\hline & Bus & $"$ & $"$ & " \\
\hline & Rail & “ & 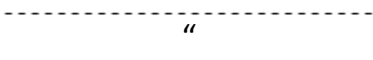 & $"$ \\
\hline & Domestic air & " & $"$ & $"$ \\
\hline \multicolumn{5}{|c|}{ Freight Transport } \\
\hline & Truck & $\begin{array}{l}\text { Tonne- } \\
\text { kilometre }\end{array}$ & Share of tonne-kilometre & $\begin{array}{l}\text { Energy / tonne- } \\
\text { kilometre }\end{array}$ \\
\hline & Rail & & ") & $" \cdots$ \\
\hline & Domestic ship & 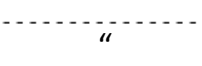 & $\bar{\prime}$ & $"$ \\
\hline
\end{tabular}

Table B.1.: Summary of variables used for the decomposition 


\begin{tabular}{|c|c|c|c|c|}
\hline Sector & Sub-sector & Activity (A) & Structure (S) & Intensity (I) \\
\hline \multicolumn{5}{|c|}{ Manufacturing $^{4}$} \\
\hline ISIC 15-16 & $\begin{array}{l}\text { Food, beverage and } \\
\text { tobacco }\end{array}$ & Value added & Share of value added & Energy/value added \\
\hline ISIC 21-22 & $\begin{array}{l}\text { Paper, pulp and } \\
\text { printing }\end{array}$ & “ & “ & " \\
\hline ISIC 24 & Chemicals & \# & $"$ & \\
\hline ISIC 26 & Non-metallic minerals & & $" \overline{7}$ & $"$ \\
\hline ISIC 27 & Primary metals & $"$ & $"$ & $"$ \\
\hline ISIC $28-32$ & $\begin{array}{l}\text { Metal products and } \\
\text { equipment }\end{array}$ & " & $"$ & $"$ \\
\hline $\begin{array}{l}\text { ISIC 17-20, } \\
25,33-37\end{array}$ & Other manufacturing & " & $"$ & " \\
\hline
\end{tabular}

\begin{tabular}{|c|c|c|c|c|}
\hline \multicolumn{5}{|l|}{ Services } \\
\hline ISIC 50-99 & Services & Value added & Share of value added & Energy/value added \\
\hline \multicolumn{5}{|c|}{ Other Industries ${ }^{3}$} \\
\hline ISIC 1-5 & Agriculture and Fishing & Value added & Share of value added & Energy/value added \\
\hline ISIC 45 & Construction & “" & "' & \\
\hline
\end{tabular}

Notes:

1) Adjusted for climate variations using heating-degree days.

2) Adjusted for household occupancy.

3) The following ISIC groups are not included in the analysis: 10-14 Mining \& Quarrying, 23 Fuel Processing, and 40-41 Electricity, gas and water supply. Industries in category "Other industries" are analysed only to a very limited extent by the IEA.

4) Based on ISIC rev. 3.1.

By introducing the dimension of fuel mix and carbon intensity (or $\mathrm{CO}_{2}$ intensity), the decomposition of energy use can be extended to address changes in $\mathrm{CO}_{2}$ emissions (G). In this case, fuel mix (F) represents changes in fuel shares (including electricity) among end-uses. Carbon intensity $(\mathrm{C})$ refers to the $\mathrm{CO}_{2}$ emissions per unit of energy used.

$$
F_{t}^{r, t}=\frac{E_{t}^{r . f}}{E_{t}^{r}} \quad C_{f}^{r, t}=\frac{G_{t}^{r, f}}{E_{t}^{r, f}}
$$

The $\mathrm{CO}_{2}$ emissions $(\mathrm{G})$ in a sector can then be decomposed into the activity, structure, energy intensity, fuel mix and carbon intensity effects according to the following formula:

$$
G_{t}=A_{t} \cdot \sum_{r}\left[S_{t}^{r} \cdot I_{t}^{r} \cdot \sum_{f \in f u e l}\left(F_{t}^{r, f} \cdot C_{t}^{r, f}\right)\right]
$$

This makes it possible to calculate the hypothetical $\mathrm{CO}_{2}$ emissions as well as $\mathrm{CO}_{2}$ savings. For example, the following two formulas present the carbon intensity effect and corresponding savings.

$$
G_{t}^{C}=\frac{A_{0} \cdot \sum_{r}\left[S_{0}^{r} \cdot I_{0}^{r} \cdot \sum_{f}\left(F_{0}^{r, f} \cdot C_{t}^{r, f}\right)\right]}{G_{0}} \quad \operatorname{CO}_{2} \text { SAVINGS } S_{t}^{C}=\frac{G_{t}}{G_{t}^{C}}-G_{t}
$$




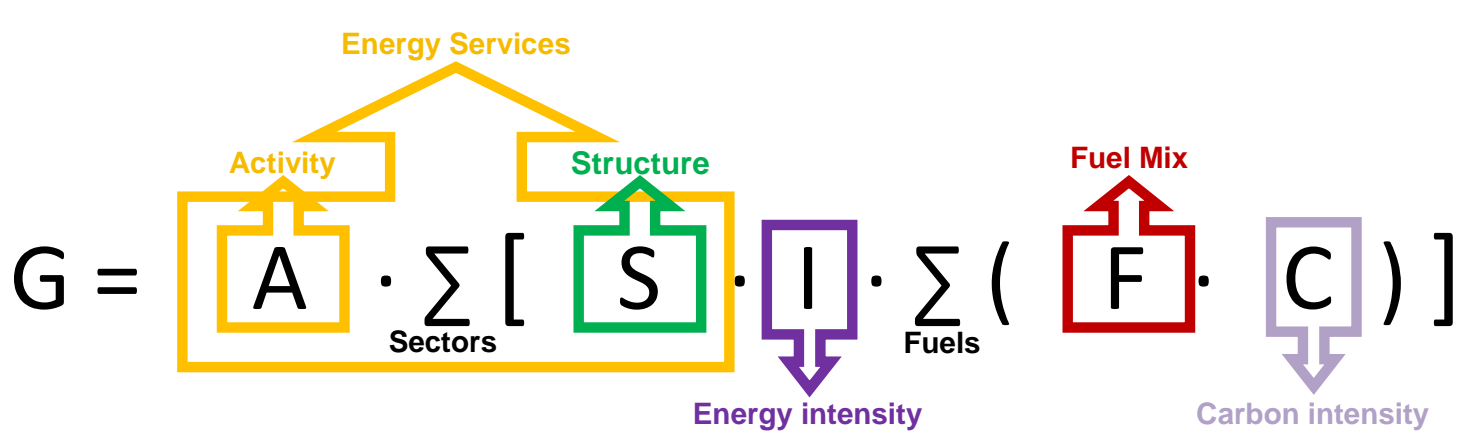

Regional aggregates for hypothetical energy use are calculated as the sum of hypothetical energy uses across all countries in a particular region. Energy savings for a region are then calculated as a difference between the hypothetical energy use and the actual energy use. The same approach is used for $\mathrm{CO}_{2}$ emissions.

A number of different index-number techniques can be used to analyse factors affecting energy use. The IEA uses the Laspeyres indices approach which is relatively simple to interpret. However, the indicator results are affected by this choice of approach, and by the selection and definition of the activity, structure and intensity variables. In addition, it is important to keep in mind that individual countries that have created their own indicators may have different results. Some of these countries have used a different decomposition method and chosen different variables.

\section{Sectoral coverage}

The analysis done by the IEA considers energy use in the manufacturing, residential, service, passenger and freight transport sectors in the categories shown in Figure B.2. It does not consider "other industries" in detail, as data for these activities are scarce.

All energy data in the IEA energy indicators publications are expressed on a net calorific value basis (using lower heating values). Data definitions are based on the methodology used in the IEA energy statistics and balances, although there are some important differences. In the IEA energy balances, coal transformation losses are included as energy transformation. The IEA indicator approach allocates these losses to the primary metals sector (ISIC 27) in which the secondary coal products are consumed. With the energy balances method, petroleum products used as feedstocks for industrial chemicals are included as non-energy use in the TFC. These products are not included at all in the indicator approach. Similarly, the energy balances approach includes energy use for refining in the transformation sector whereas the indicator approach considers refining as part of ISIC 23 (manufacture of coke, refined petroleum products and nuclear fuels), which is excluded for the indicators analysis.

The indicators analysis study also excludes some aspects of transportation such as natural gas pipelines, and fuel use for private boats and military vehicles. Both approaches exclude international marine bunkers from TFC. International air traffic is included in the IEA statistics but not in the indicator approach.

Further information on the scope of individual sectors is provided below.

The manufacturing sector of industry produces finished goods or products for use by other businesses, for sale to domestic consumers or for export. 
The residential sector includes those activities related to private dwellings. It covers all energyusing activities in apartments and houses, including space and water heating, cooking, lighting and the use of appliances.

The service sector includes activities related to trade, finance, real estate, public administration, health, education and commercial services.

Passenger transport includes the movement of people by road, rail, water and air. Passenger road transport is further subdivided into cars and buses. International air travel is excluded due to a lack of consistent and comparable data for IEA countries.

Freight transport includes the movement of goods by road, rail and water. It excludes air freight transport because of a lack of comprehensive and consistent data for this mode.

Figure B.2. Disaggregation of sectors, sub-sectors and end-uses in IEA energy indicators approach

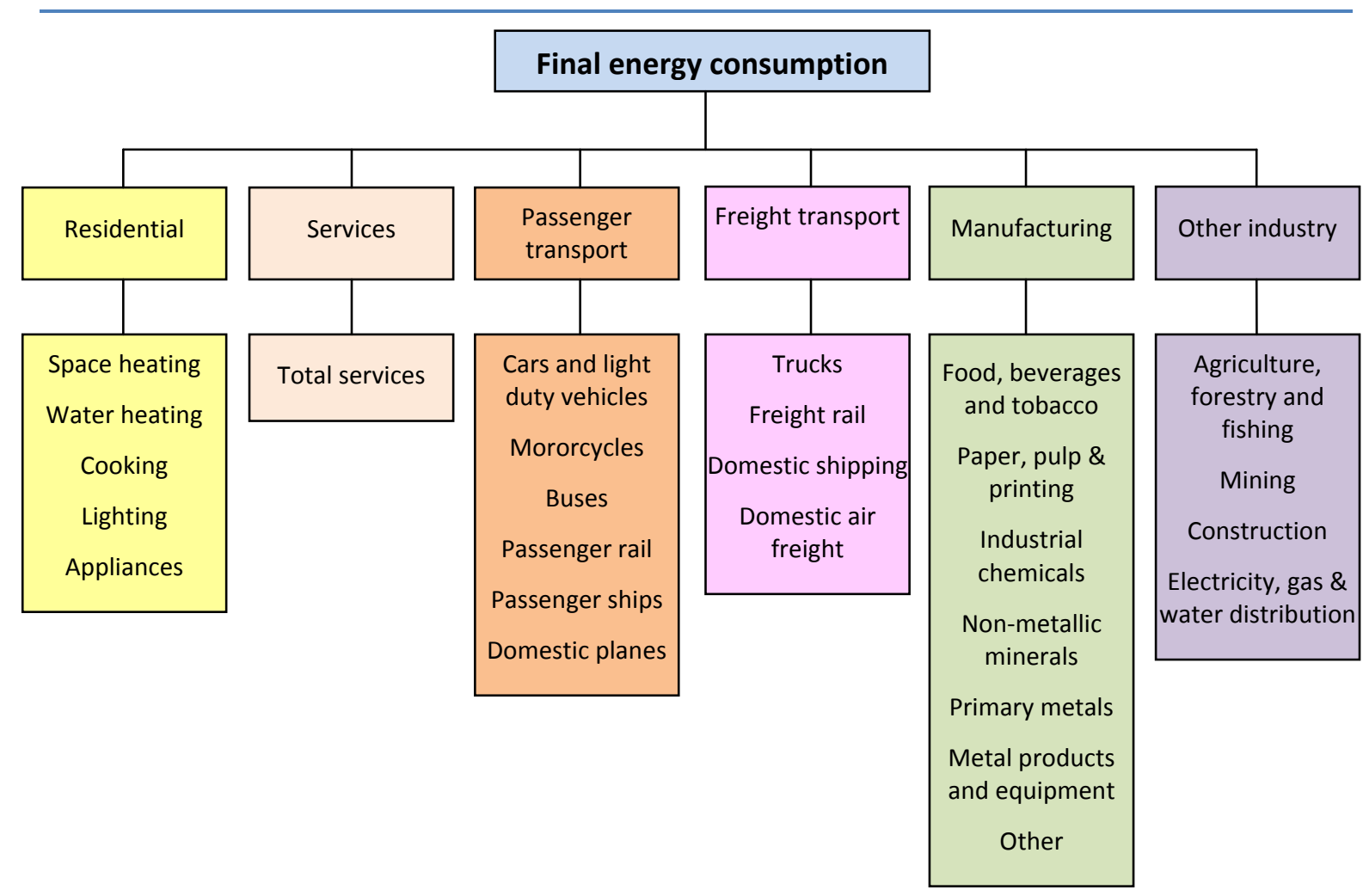




\section{Annex C. References}

IEA (International Energy Agency) (2004), Coming in From the Cold: Improving District Heating Policy in Transition Economies, IEA/OECD, Paris, www.iea.org/publications/free_new_Desc.asp?PUBS_ID=1469

IEA (2008), Worldwide Trends in Energy Use and Efficiency: Key Insights from IEA Indicators Analysis, IEA/OECD, Paris, www.iea.org/publications/free_new_Desc.asp?PUBS_ID 2026 .

IEA (2009), Energy Technology Transitions for Industry: Strategies for the Next Industrial Revolution, IEA/OECD, Paris, www.iea.org/publications/free_new_Desc.asp?PUBS_ID=2104.

IEA (2010), Energy Technology Perspectives 2010: Scenarios \& Strategies to 2050, IEA/OECD, Paris, www.iea.org/publications/free_new_Desc.asp?PUBS_ID $=2100$.

Rosstat (2010a), Main Indicators of Transport Performances in Russia, Rosstat, Moscow, www.infostat.ru/eng/catalog.html?id=391\&page=info.

Rosstat (2010b), Transport in Russia, Rosstat, Moscow.

World Bank (2008), Energy Efficiency in Russia: Untapped Reserves, World Bank, Moscow. 


\section{Annex D. Abbreviations, acronyms and units}

\section{APEC Asia-Pacific Economic Cooperation}

$\mathrm{bcm}$ billion of cubic metres

Page $152 \quad \mathrm{CO}_{2} \quad$ carbon dioxide

GDP Gross domestic product

GHG Greenhouse gas

IEA International Energy Agency

ISIC International standard industrial classification

LDV Light-duty vehicles

MJ Megajoules ( $10^{6}$ joules)

NIIAT Scientific and Research Institute of Motor Transport (Moscow)

PJ Petajoules ( $10^{15}$ joules)

Pkm passenger-kilometres

Rosstat Federal State Statistics Service (Russia)

SUV Sport utility vehicle

TFC Total final energy consumption

TPES Total primary energy supply 


\section{iea}

\section{International Energy Agency}
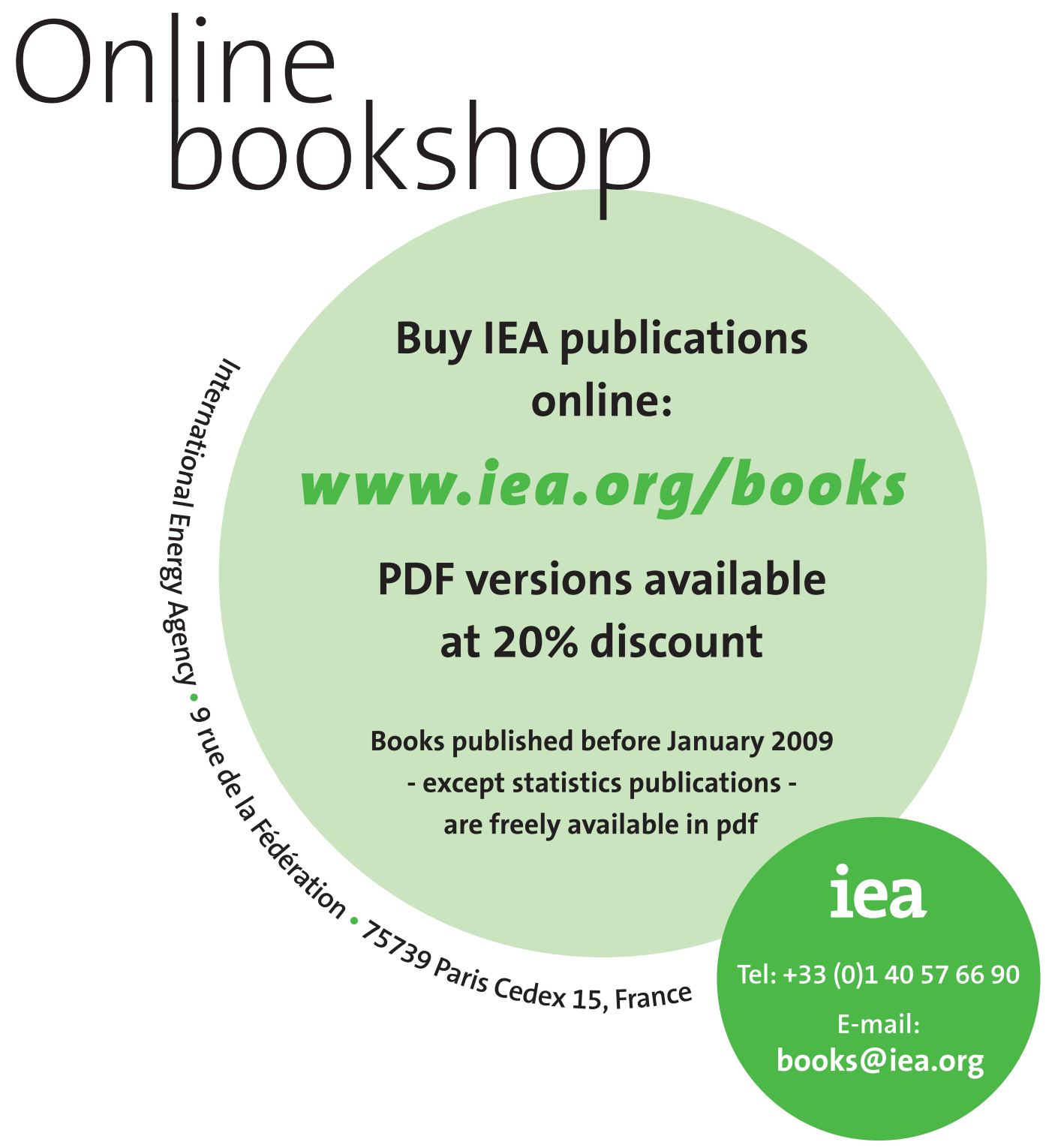
